\title{
Haber Söyleminde ‘Öteki'yi Aramak: Suriyeli Mülteciler Örneği
}

\author{
Abdulkadir Gölcü' \\ Ayșe Nur Dağ|²
}

\begin{abstract}
Özet
2011 yılının mart ayında Arap Baharı'nın bir uzantısı olarak Suriye'de başlayan toplumsal hareketler zamanla bir iç savaşa dönüşerek, ülkeyi etkisi altına almıştır. Türkiye de bu iç savaştan etkilenmiş ve sayıları yaklaşık 4 milyonu bulan Suriyeli mülteciyi kabul etmiştir. Medyanın bu kitlesel göçü ele alışı ve göç edenleri nasıl temsil ettiği de önem kazanmıştır. Çünkü medya üzerinden temsil edilme süreçlerindeki ayrıştırıcı fikirler ve tutumlar, toplumsal hayatta somut davranışlara dönüşebilmektedir. Suriyeli mültecilerin haber metinlerinde ve söylemlerinde öteki olarak temsili, toplumsal bilinçte oluşan Suriyeli mülteci figürü ile doğrudan ilgilidir. Bu çalışma kapsamında da Suriyeli mültecilerin Türk yazılı basınında öteki olarak nasıl temsil edildiği analiz edilmiştir. Özellikle haber medyasında üretilen söylemler dikkate alınarak haber metinlerindeki toplumsal eşitsizliği, ayrımcılığı Suriyeli mülteciler örneği üzerinden ortaya çıkarmak amaçlanmıştır. Haber metinlerinin analizi için yöntem olarak Teun van Dijk'ın çerçevesini oluşturduğu eleştirel söylem analizi yöntemi kullanıımıştır. Çalışma kapsamında Hürriyet, Milliyet ve Sabah gazeteleri örneklem olarak seçilmiştir. Bu gazeteler; kitle gazeteleri olmaları, yüksek satıș oranlarına sahip olmaları ve ana akım gazeteler olarak tanımlanmış olmaları nedeniyle örneklem olarak seçilmişlerdir. $\mathrm{Bu}$ gazetelerde 2011-2017 yılları arasında Suriyeli mültecileri konu edinerek yayınlanan haberler analize tabi tutulmuştur. Yapılan analizler sonucunda Suriyeli mültecilerin; Türkiye'de kaldıkları süreyle de orantılı olarak, ekonomi, eğitim, dil, sağlık, yasal düzenlemeler, sosyal uyum gibi konularda sorunlu, ayrıştırıcı ve ötekileştirici söylemleri üzerinden temsil edildikleri görülmüştür.
\end{abstract}

Anahtar Kelimeler: Suriyeli, Mülteci, Öteki, Haber Söylemi, Eleştirel Söylem Analizi.

\section{Searching for the "Others" in the News Discourse: Syrian Refugees Example}

\begin{abstract}
The social movements that started in Syria in March 2011 as an extension of the Arab Spring turned into a civil war and affected the country in time. Turkey has been influenced by this civil war and has accepted almost 4 million Syrian refugees. It has also become important how the media addressed this mass immigration and represented the immigrants, because, the separating ideas and attitudes in the
\end{abstract}

1 Selçuk Üniversitesi İletişim Fakültesi Gazetecilik Bölümü Öğretim Üyesi

2 Selçuk Üniversitesi Sosyal Bilimler Enstitüsü Yüksek Lisans Öğrencisi 
processes of representation through media can transform into concrete behaviours in social life. The representation of the Syrian refugees as the "others" in the news reports and discourses is directly related to the Syrian refugee thought formed in the social consciousness. This study analyses how the Syrian refugees are represented as the "others" in the Turkish printed media. Considering the discourses produced in the news media, in particular, the purpose of this study was to reveal the social inequality and the discrimination in the news reports through the example of Syrian refugees. The critical discourse analysis method that Teun van Dijk framed was used for the analysis of news reports. As part of the study, Hürriyet, Milliyet and Sabah newspapers were selected as samples. The news reports published in these newspapers were analysed for the news reports published between 2011 and 2017 related to Syrian refugees. As a result of the analyses, Syrian refugees were observed to be represented on the basis of the problematic, separating and alienation discourses in various issues such as economy, education, language, health, legal regulations, social adaptation, etc. in proportion to their course of stay in Turkey.

Keywords: Syrian, Refugee, Other, News Discourse, Critical Discourse Analysis. 


\section{Giriș}

$\mathrm{M}$ ültecilik; tarihsel olarak dünyayı küresel ölçekte etkileme gücüne sahip bir sorun olarak değerlendirilmiştir. Farklı toplumların karşılaşması üzerine inşa edilmiş olan göç hareketlerinin doğal bir sonucu olan mültecilik, hem tarihsel süreçler üzerinde hem de modern insanın gündelik hayatında çok yönlü bir etkileme gücüne sahip olmuştur. Bu sorun bir tanımlama ya da tanımlanma zorunluğunu da beraberinde getirmiştir. Birleşmiş Milletler Mülteciler Yüksek Komiserliği'nin (1998: 68) yapmış olduğu tanımlamada; savaş gibi, zorlayıcı koşulların etkisinde kalan toplulukların başka ülkelere göç etmesi sonucu ortaya çıkan fiili durumdaki geçici kimlik durumu mülteci olarak nitelenmektedir.

15 Mart 2011 tarihinde, Arap Baharı olarak bilinen gösteriler ile başlayan Suriye Krizi'nde Nisan ayı itibariyle ortaya çıkan çatışma ortamı ülkeyi bir iç savaşa doğru sürüklemiş, iç savaşın ülke geneline yayılması ve hayatın yaşanmaz duruma gelmesiyle birlikte kendilerini risk altında hisseden, temel ihtiyaçlarını ve güvenliklerini karşılayamaz duruma düşen Suriyeliler çareyi ülkelerini terk etmekte bulmuşlardır (Tunç, 2015: 35). 2011 yılından beri Suriye'de devam edegelen bu durum Suriye yönetimi ile komşu ülkeler arasındaki ilişkileri de etkilemiştir. Suriye'de yaşanan iç savaşın sonuçlarını en fazla yaşayan ülkelerden biri kuşkusuz Türkiye olmuştur. Birleşmiş Milletler Mülteciler Yüksek Komiserliği'nin (2017) verilerine göre; bu gelişmeler sonucunda 12 milyon Suriyeli evini terk etmek zorunda kalmıştır. Bu insanların yaklaşık 5,2 milyonu ise çevre ülkeler Türkiye, Lübnan, Ürdün, Irak ve Mısır'a sığınmıştır. Bu sayıya ek olarak yaklaşık 1 milyon kadar Suriyeli Avrupa ülkelerine sığınmış durumdadır. Bu gelişmelerden kaynaklı olarak yaşanan kitlesel iç ve dış göç, dünyanın en büyük insani krizlerinden birisinin ortaya çıkmasına da neden olmuştur. Bu krizle birlikte, Nisan ayında Suriye'den Türkiye'ye doğru sığınmacı akını başlamış ve ilk kafile 29 Nisan 2011 tarihinde Türkiye topraklarına giriş yapmıştır (Tunç, 2015: 35-36). Suriyeli mülteci krizi beş yılı aşkın bir süredir hem Türkiye ve diğer komşu ülkelerde hem de Avrupa ülkelerinde etkisini artırarak sürdürmektedir. Avrupa tarihinde en büyük göç dalgası olarak nitelendirilen bu süreçte Türkiye önemli bir role sahiptir ve bu göç dalgasının yükünü önemli ölçüde üstlenmiştir. Birleşmiş Milletler Mülteci Ajansı'nın güncel verilerine göre, hâlihazırda iki buçuk milyondan fazla kayıtı Suriyeli mülteci Türkiye sınırları içerisinde bulunmaktadır (Özdemir ve Öner-Özkan, 2016: 229).

Türkiye'nin Suriyelilere yönelik açık kapı politikası ile kamuoyu, başlarda Suriyelilerin temel insani ihtiyaçlarının karşılanabilmesi konusuna yoğunlaşmıştır. Zaten kısa süreli bir nüfus hareketi olacağı öngörüsü kabul edildiği için Türkiye kamuoyunda, Suriyeliler "misafir" olarak nitelendirilmiş, fakat "misafirlerin" kalma sürenin uzamasına sebep olacak gelişmelerin yaşanması ve misafir tanımının uluslararası hukukta bir karşılığının olmaması (Güçtürk, 2014), Türkiye kamuoyunda "misafirin" mülteciye dönüşmesi sürecini hızlandırmıştır. Zaten göç alan toplumların mültecilere yaklaşımı ve bakış açısı incelendiğinde; mültecilere karşı kültürel mesafe koydukları, demografik açıdan kaygı duydukları, iş ve gelir kaybı yaşadıkları, barınma ücretlerinin yükselmesinden şikâyetçi oldukları görülmektedir (Nurdoğan ve vd. 2017: 2298).

Bu çerçevede Türkiye kamuoyunda, yazılı basında ve ulusal medyada Suriyeli mültecileri içine alan değerlendirmeler sayısal anlamda hızı bir artış göstermiştir. Zaman ilerledikçe ve göç dalgaları devam ettikçe, basındaki mültecilerle ilgili konular 
değişmeye ve çeşitlenmeye de başlamıştır. Bu süreçte kamuoyunda ve yazılı basında en fazla yer alan konular, Suriyeli mültecilerin toplumsal uyumu, Suriyeli işçiler, Suriyelilerin kamplarda mı şehirlerde mi yaşaması gerektiği, Suriyelilerin çalışma şartları, ülkelerine ne zaman dönecekleri, Suriyeli dilenciler, Suriyelilerin karıştığı adli suçlar gibi çeşitli başlıklar altında toplanmıştır. Bu konuların Türkiye kamuoyunda sürekli olarak tartışılmasında basının rolü oldukça fazladır. Ayrıca yazılı basında Suriyeli mülteci imajının çeşitli şekillerde ve şablonlarda aktarımı, Türkiye kamuoyunun Suriyeli mültecilere bakış açısına da belirleyici bir şekilde yön vermektedir. Seydi'nin (2014) yapmış olduğu çalışmada, Suriyeli mültecilerin Türkiye'de eğitim sistemine büyük bir yük getirdiği, eğitim kalitesinin düşmesine ve çözülmesi güç problemlere neden olduğu yönündeki anlatımların haber medyası tarafından yoğun olarak işlendiği görülmüştür. Boztepe (2017) yaptığı araştırmada, televizyon haberlerinde Suriyeli mültecilerin temsilinin olumsuzluk içeren, biz/öteki ayrımına dayanan ve yasa dışılığı ön plana çıkaran bir bağlam üzerinden gerçekleştiğini dile getirmektedir. Göker ve Keskin (2015) yaptıkları çalışmada farklı siyasal perspektif ve bağlamlara sahip gazetelerde Suriyeli mültecilerin temsillerini ele almıştır. Çalışma sonucuna göre bu gazetelerin Suriyeli mültecilere yönelik yaptığı haberlerde "olumsuzlayıcı" bir içeriğe sahip olduğu görülmektedir.

$\mathrm{Bu}$ çalışmanın amacı Suriyeli mültecilerin gazete haberlerindeki temsillerinde ötekileştirilme sorunsalını ortaya koymak olarak belirlenmiştir. Bu sorunsal çerçevesinde haber metinlerinde Suriyeli mültecilerin nasıl temsil edildiği, bu temsil süreçlerinde kullanılan anlatı yapılarının ötekileştirici tanımlamalar barındırıp barındırmadı̆̆ı, aynı zamanda haber metinlerinde üretilmiş olan söylemlerin ötekileştirici unsurlar içerip içermediği tespit edilmeye çalışılacaktır. Bunun yanı sıra Suriyeli mülteciler hakkında; toplumsal uyumsuzluk, kültürel farklılık ve ülke ekonomisine zararları gibi çok farklı tipolojilerin de basın tarafından ele alınarak, kamuoyuna nasıl servis edildiği ele alınacaktır. Bu kapsamda haber metinlerinin ve metinlerde üretilen söylemlerin analiz edilmesi gerekmektedir. Haber metinlerindeki ayrıştırıcı-ötekileştirici anlatı yapılarının ve haber söylemlerinin analizlerinin yapılabilmesi için eleştirel paradigmanın disiplinlerarası bir bağlamda yapmış olduğu yöntembilimsel katkı olan eleştirel söylem analizi yöntemi kullanılacaktır. Söylem analizi yönteminin haberi üreten makro ve mikro yapıları analiz ederek ortaya koyduğu daha sistematik yaklaşım yerine; eleştirel söylem analizi yöntemi haber metnini bütüncül bir şekilde ele alarak makro ve mikro yapılar arasında bir köprü görevi yerine getirmektedir. Bu bağlamda eleştirel söylem analizi yöntemi; haberin üretim sürecine hakim olan dil, dilin kullanımı, toplumsal yapıdaki iktidar ilişkileri, hegemonik anlatılar ve sosyal gruplar arasındaki eşitsizlik gibi toplumsal bilince dönük çağrışımları analiz ederek ortaya koymaktadır (van Dijk, 2001: 354). Bu bağlamda van Dijk (1995: 17-18) analiz sürecinde eleştirel söylem çözümlemesini söylem analizinin bir alt disiplini olarak karakterize etmek yerine, onu metnin ve konuşmanın eleştirel bir yaklaşımla ya da bakış açısıyla ele alınması şeklinde karakterize etmek gerektiğini dile getirmektedir. Teun van Dijk bu çerçevede eleştirel söylem analizinin nasıl yapılması gerektiğini birkaç maddede özetlemiştir:

Eleştirel söylem çözümlemesi toplum ve söylem arasındaki eşitsizlik ilişkilerini disiplinlerarası bir şekilde oraya koymayı amaçlamaktadır.

Eleştirel söylem çözümlemesi; fonoloji, sentaks, semantik, stil, retorik, şematik yapı, konuşma edimi, pragmatik strateji ve etkileşim vb. gibi söyleme ait bütün 
boyutları ve aşamaları dikkate alarak yaklaşan ve onu ele alan bir yöntemdir.

Eleştirel söylem analizi uygulanarak yapılan birçok çalışmada; sadece metnin kelime özelliklerine odaklanmak yerine, bütün iletişimsel eylemleri ele alan bir anlayış oluşmuştur.

Eleştirel söylem çözümlemesi söylem analizi sürecinde toplumsal yapıda varolan iktidar ilişkilerine, eşitsizliklere ve hegemonik yapılara odaklanmaktadır.

Eleştirel söylem çözümlemesi sayesinde toplumsal yapıda varolan eşitsizliklerin ve bu eşitsizleri gizleyen ideolojik işleyişin ortaya çıkarılması sağlanmaktadır.

Teun van Dijk (1993: 252) diğer söylem çözümlemelerinin aksine, eleştirel söylem çözümlemesi yapan kişinin sosyo-politik duruşunu, bakış açısını, prensiplerini analiz sürecinde belirgin bir şekilde dile getirmesi gerektiğini hatırlatmaktadır. Zaten toplumsal yapıdaki eşitsizlik ilişkilerini ortaya koyan birisi oldukça politik bir tutumla bu işi yapmaktadır. Ayrıca van Dijk uzun süredir toplumsal eşitsizliklere maruz kalan bir kesim ile söylem analizi yapan kişinin dayanışma içerisinde olması gerektiğini de aktarmaktadır. Bu çalışma kapsamında da daha önce dile getirilmiş olan araştırma sorunsalları üzerinden, Suriyeli mültecilerin Türk yazılı basınında haber metinlerindeki temsilleri ve bu temsillerin oluşumunda ayrıştırıcı-ötekileştirici tanımlamalar ve söylemlerin etkisi toplumsal eşitsizlikler üzerinden analiz edilecektir.

\section{Öteki Kavramı}

Alman Hukuk Profesörü Günter Frankenberg'e öteki, başka ülkede doğan, devlete yabancı, ait olmayan, mülteci ya da turisttir (Onur,2003). Herhangi bir toplum içinde varlığını sürdüren din ve etnik köken bakımından sayıca az olan gruplar da toplumun üyeleri açısından birer öteki olarak algılanır. Yani öteki olan bir topluluk, bir grup, bir etnik köken ya da kişi olabilir. Bir kavram olarak öteki, ön yargıların ve ayrımcılığın bir arada görüldüğü bütüncül bir süreçtir. Ben veya bizden farklı olarak tanımlanır. Bu tanımlamayla insanlar kendi kimliğini oluşturur. Kimliğin öteki üzerinden inşa sürecinde öteki, doğası gereği olumsuzluk barındıran taraftır (Özsüer, 2012). Buehler (2011: 646) ötekinin inşası ile ilgili savını, Sigmund Freud'un modern psikolojide ortaya koyduğu "bireylerin, itiraf edilmemiş olumsuz karakter özelliklerini diğer insanlara yansıttıkları" yaklaşımına dayandırmaktadır. Buna göre birey, olumsuz bulduğu ya da itiraf etmek istemediği özelliklerini başka birey veya gruba bilinçdışı olarak yansıtmakta, dolayısıyla bir bakıma 'kötü', somutlaştırılmış olmaktadır. Bir başka ifadeyle, "biz/ onları (ötekiyi/düşmanı), kendi kötücül öznel ya da nesnel imgelerimizi dışsallaştırmak amacıyla kullanır ve kabul edilemez düşüncelerimizin yansıtmalarıyla bu imgelere zemin oluştururuz. Böylece, 'kötücül olan öteki'nin psikolojisi oluşturulmakta ve aynı yansıtma ilkesi, kabile, millet, din gibi insan grupları için de kullanılmaktadır.

Kaya'ya (2015:49) göre günümüz dünyasında modern insanın hayat akışı; "ötekine, yabancıya, göçmene, azınlığa, bizden olmayana karşı duyulan ve güvenlik söylemiyle üretilen, modern insanın her an risk altında olduğunu anımsatan" bir anlayışla paralel olarak ilerlemektedir. Bauman (2009: 52) da kimlik inşasında iyi özelliklerden oluşan 'biz'in dışında kalan her grubun kötü özelliklerle tanımlanan 'onlar'ı oluşturduğunu 
söyler. 'Onlar' yabancılaştırılarak ötekileştirilir. Sosyolojide iç ve dış grup olarak nitelendirilen biz ve onlar, ancak karşılıklı çatışma içinde varlıklarını sürdürebilmektedir. Benzer bir bakış açısından yola çıkan Edward Said (1999: 127) ise Batı'nın Doğu'yu ötekileştirmesi üzerinden bu süreci şöyle açıklar: 'Doğu'yu ötekileştiren Batı aynı zamanda kendi kimliğini de oluşturmaktadır. Belirli bir taraf etkin olsa da biz ve ötekinin yaratılması karşılıklı bir süreçtir. Bizi oluşturan, bizim oluşturduğumuz ötekidir.' Said, öteki hakkındaki genel kalıpların önyargıları oluşturduğunu dile getirerek, önyargılarla ötekinin düşman olarak görünmeye başladığını söyler.

Bauman (2005: 112) modern zamanlarda evrensel bir ötekinin oluşturulduğu ve bu kişinin yabancı olarak tanımlandığını dile getirmektedir. Bu çerçevede yabancı modern kent yaşamında ne yapacağı tam olarak kestirilemeyen ve kendisine kuşku ile bakılan bir konuma yerleştirildiği için, kent hayatı içinde sınırlı mekânlarda hapsedilip kontrol altına alınarak pasifize edilmiş bir düşman konumunda sunulmaktadır. Ötekinin düşman olarak görülmesi, ötekileştirme sonucu oluşur. Ötekileştirme, toplum içinde farklı ve marjinal olarak tanımlanan kesimleri dışlamayı ve pasifize etmeyi amaçlayan bir etiketleme biçimidir (Şeker ve Şimşek, 2011: 486). Öteki sorunsalına birey boyutundan bakıldığında ötekinin oluşturulmasında bireyin psikolojik açıdan sağlığını sürdürebilmesi bakımından bir düșman yaratarak kendinde gördüğü eksiklikleri ve yetersizlikleri "ötekine" yüklemesi, kendisine olan öfkesini ona yönelterek benliğini sürdürmesi durumunun söz konusu olduğu görülmektedir (Uluç, 2009: 45).

Bu bağlamda ötekileştirme sürecinde birey ötekine yüklediği olumsuz niteliklerle kendini arındırır. Kendisine yüklenen olumsuz misyonla etiketlenen öteki, her şeyin sorumlusu olarak 'günah keçisi' seçilir ve tehdit unsuru olarak algılanır (Özsüer, 2012). Benzer şekilde Kearney (2012: 54) de günah keçisinin toplumsal işlevine vurgu yaparak, toplumu oluşturan bireylerin bir arada var olması için gerek duyulan asli mutabakatın, bütün suçun bu bireylerin oluşturduğu bizin dışında kalan bir yabancıya atılmasıyla sağlanacağını dile getirmektedir. Bu süreçte günah keçileri toplumsal düzeydeki sorunların muhatabı ve nedeni olarak kabul edilmekte ve kendilerine dönük yoğun bir öfke dalgasının muhatabı olmak zorunda kalmaktadırlar. Bu durum esasında toplumsal bloktaki çatlakların günah keçileri üzerinden ortadan kaldırılmasına ve "öteki" karşısında "biz"in inşasıyla sonuçlanmaktadır. Yabancının günah keçisine dönüştürülmesi, bu bakımdan oldukça kolaydır. Çünkü yabancı, aslında bulunması gereken yerde olmayan ve çoğu zaman korunmasız bir kişidir ya da toplumsal bir gruptur. Mülteciler bu anlamda hem yabancı hem de günah keçisi olmaya oldukça yakındır (Göker ve Keskin, 2015: 232).

\section{Medya ve Öteki}

Medya organları hakim sosyo-kültürel ve ekonomi-politik yapı doğrultusunda bir takım dilsel ve göstergesel kodlar geliştirerek toplumsal yapıda var olan temsil yapısı ve söylemler üzerinde 'normal' ve 'marjinal' davranış olarak adlandırılan tanımlama kalıpları belirlemektedir. Sürekli olarak yenilenen bu kalıplar sayesinde medya organları yeni fikirlerle uğraşmakta, toplumsal kuralları yeniden onaylamakta, sınırları yeniden çizmekte ve tanımlamaktadır (Shoemaker ve Reese, 2002). Bu ifadeyi daha da sade bir anlatımla aktaran Akçalı'ya (2006: 13) göre; medyanın ürettiği metin bizi dünyadan haberdar eder, ancak bu dünya, bizim yaşadığımızı sandığımız dünya değil, haberdar olduğumuz dünyadır. Bu çerçevede özellikle biz ve onlar karşıtığı üzerinden 
bir tanımlama yapma süreci işlerlik kazanmaktadır. Biz ve onlar karşıtlığı ile şekillenen ötekinin oluşum ve temsil süreçleri incelendiğinde, medya içeriklerinin ayrıştırıcıötekileştirici söylemleri pekiştirdiği görülmektedir. Kamuoyu ise medya üzerinden zihinlere yerleştirilen etiketlemeleri, ayrıştırıcı tanımlamaları ve konumlandırmaları bilinçli ya da bilinçsiz bir şekilde kabul etmekte ve bu doğrultuda davranış ve düşünce kalıpları geliştirmektedir.

Medya eşitsizlik üzerinde inşa edilmiş olan sosyal ilişkilerin kamusal sunumunda belirleyici bir rol üstlenmektedir. Bu sunum süreçlerinde medya izler kitleyi sürekli olarak 'bizden olanlar' ve 'bizden olmayanlar', 'bizler' ve 'onlar', 'içeridekiler' ve 'dışarıdakiler', 'vatandaşlar' ve 'yabancılar', 'normaller' ve 'sapkınlar', 'dostlar ve düşmanlar', 'batılılar' ve 'geri kalanlar' gibi çeşitli ayrıştırma süreçlerine davet etmektedir. Bu sayede toplum genelinde harekete geçirilmiş olan toplumsal çıkarlar, toplumsal platformda birbirinden ayırt edilir, farklılaşır ve çoğunlukla ayrımcılığa karşı savunmasız hale getirilmiş olur (Cottle, 2000: 2). Bu bağlamda medyada yapılan ayrımcılık, niteliği gereği gerçek yaşam alanlarındaki ayrımcılığa benzer. Ancak medyadaki ayrımcılık, sınırlı bir ayrımcılık olmasına rağmen, paradoksal biçimde yaşamın bütün diğer alanlarındaki ayrımcılığın ötesine geçen zararlar üretme potansiyeline sahiptir (Çelenk, 2010: 222). Sonuç olarak medya, kendisi üzerinden oluşturulan ötekileştiren ve ayrıştıran konumlandırmaları profesyonelce kurgulanmış olumsuz olay örgüleriyle birlikte sunarak, bireylerde ötekiye karşı önyargılar geliştirir ve ötekine karşı olanlar arasında bilişsel düzeyde karşıt bir birlikteliğin de oluşmasını hızlandırır.

Medya ayrıca 'biz' ve 'ötekiler' formülü ile topluluk duygusunun üretildiği ulusal ve bir o kadar da politik bir hayal de oluşturmaktadır (Uluç, 2009: 126). Bu bağlamda medyada sunulan öteki, aynı zamanda o toplumdaki milli kimliğin de yeniden üretimini gerçekleştirmektedir. Bu yeniden üretim toplumsal birliğin korunması amacıyla kolektif hafızanın beslenmesine yönelik, 'öteki'nin bir tehdit olarak varlığını sağlamlaştıran ya da 'öteki'ne karşı düşmanlığı canlı tutan korku üretimine yönelik temsillerle sağlanmaktadır (Ünür, 2013: 27). Hobsbawm (2006: 209) da kendini olumlu nitelikleriyle tanımlayan milli kimliğin, olumsuz nitelikleri ya da eksiklikleri çoğunlukla 'öteki'ne yüklediğini belirterek, etnik kökenin çağrısıyla tehdit unsuru olan 'öteki'ne karşı bütünlük oluşturma için protestoların gerçekleştirildiği dile getirir. Bu bağlamda 'biz'e karşı 'onlar', yani ötekiler; kamusal tehditler ve kirletici unsurlar olarak bulunmaktadır.

Bireyler ya da gruplar medyada, oluşturulmuş kalıp yargılarla toplumsal olarak sınıflandırılmaktadır. Bu kalıp yargılar, temsil edilen insan ya da gruplar hakkındaki önyargılarla, olumsuz yaklaşımlarla ilgilidir (Uluç, 2009: 121). Bu çerçevede olumlu ya da olumsuz olarak sunulacak gruplar, kişiler ya da topluluklar en başından belirlenmiştir. Bireylerin medyadaki temsillerine bakıldığında "biz" olarak tanımlanan kesimin seçkin olarak yansıtıldığı olumlu temsillere karşın; "onlar"ın ise yoksul, zayıf, çaresiz, hastalıklı, göçmen, farklı gibi stereotipler üzerinden yansıtıldığı olumsuz temsiller göze çarpmaktadır. Farklı kimliklere sahip olanlar genellikle belirli stereotiplerle temsil edilmektedir. Stereotipler, bazı şeyleri kolay ve kısa yoldan anlatma imkanı verirken, aynı zamanda temsil edilen gruplar hakkında ön yargılar da üretir. Çünkü bu temsil biçimi, onu yalnızca bir bölümüyle, bazı özelliklerini olduğundan daha abartılı olarak sunmak biçiminde gerçekleşmektedir (Akca, 2009: 101). 
sunulan kimliklerin başında, kadınların, alt sosyo-ekonomik düzeydeki yoksulların, başlarına felaket gelmiş sıradan insanların, suç ve şiddet mağduru çocukların yer aldığının altını çizer. Suçluların, hırsızların, cinsel tercihi farklı olanların ise, sapkınlar ya da normalin dışında olanlar grubunda temsil edildiğini belirtir. Medya 'öteki'yi bazen bir hırsız, bir cinayet zanlısı olarak da ön plana çıkarır. Bunu yaparken, 'öteki'nin ait olduğu toplumsal grupları açık bir hedef haline getirir. Sonuç olarak, medya 'biz' ve 'ötekiler' formülü ile ulusal topluluklarda kimin içeride kimin de dışarıda olduğunu belirtirken toplumun sınırlarını belirleyen bir 'sosyal harita' oluşumuna da yardımcı olur (Uluç, 2009: 124).

Medya temsillerinde ötekileştirme her zaman gösterme ya da sunma ile değil, kimi zaman da bir okuyucunun/ izleyicinin metinde görmeyi umduğu ama metin içinde olmamakla, metinde yer bulamamakla da ilgilidir. Metinsel yokluklar ya da görmezden gelmeler belirli bir dünyanın çerçevelenmesinde yardımcı olur, ötekileştirme medya ürününde eksiklikler, yoksunluklar ile karakterize edilmektedir (Uluç, 2009: 130-131). Sonuç olarak, medya üzerinden yapılan sorunlu temsiller ya da medyada yok sayarak kamusal bilinçten uzak tutulma gibi yöntemler; sosyal düzeni bozanların ötekiler olduğu inancını genele yaymakta ve ötekilerin kontrol altına alınması durumunda sosyal düzenin sorunsuz işleyeceğine olan inancı pekiştirmektedir.

\section{Haber Söyleminde 'Öteki'}

Fairclough'a (2001: 54) göre medya söyleminin sahip olduğu gizli güç ve bu gücü kullanmak isteyenlerin kapasitesi haber aktarmadaki ve diğer medyatik etkinliklerdeki sistematik eğilimlere bağlı bulunmaktadır. Bu bağlamda sadece metin oldukça önemsizdir: Medyanın etkisi, nedensellik ve faillik konularını ele almanın ve okuyucuyu konumlandırma gibi süreçler üzerinden belirli şekillerinin tekrarı aracılığıyla birikerek oluşmaktadır. İnceoğlu ve Çomak'a (2009: 35) göre ise; ideolojiler kendilerini dil ile ifade edip biçimlendirirler. Dili kullananların seçtikleri sözcükler, sözcük öbekleri, konuşma biçimi, anlatımı ve hatta cümle kurma becerileri söylemin oluşmasında belirleyici etkenlerdir. Dolayısıyla dilin kullanımıyla söylem oluşmaktadır. Bu bağlamda gücünü sözcüklerden, söyleyenlerden ve toplumsal koşullardan alarak söyleme dönüşen medya metinleri ve haberler, belirli bir dil çerçevesi içerisinde söylemsel pratikler olarak toplumsal bilinçte dolaşıma sokulmaktadır. Benzer şekilde van Dijk (1989: 177) da toplumsal yapıda baskın konumda olanların diğerleri üzerinde üretmiş oldukları hakimiyetin ideolojik boyutunun özellikle haber medyası üzerinden dolaşıma sokulan söylemler aracılığı ile sağlandığını dile getirmektedir. van Dijk bu süreçte medya tarafından en çok yayılan ve meşrulaştırılan söylemlerin cinsiyetçilik, ırkçılık ve toplumsal sınıfa aidiyet olduğunun da altını çizmektedir. Yine van Dijk (2000: 36) bir başka çalışmasında toplumsal yapıdaki elitlerin medya üzerinden hareket ederek, modern enformasyon toplumlarında insanların başkaları hakkındaki düşüncelerini şekillendiren medya söylemleri üzerinde belirleyici bir güce ve sorumluluğa kavuştuklarını dile getirmektedir.

Bu konuya benzer bir bakış açısıyla yaklaşan Kearney’e (2012: 56) göre de bugün modern toplumsal yapılarda varolan medya; yabancı yaftasına maruz kalan bireylerin veya azınlıkların dışlanmasında belirleyici bir rol oynamaktadır. Fairclough ve Wodak'a göre (1997: 258) bu söylemsel pratikler sosyal sınıflar arasındaki, kadın ile erkek arasındaki ve etnik/ kültürel azınlıklar ile çoğunluklar arasındaki eşitsiz güç ilişkilerinin 
üretilmesine ve yeniden üretilmesine yardım ederek şeylerin ve insanların pozisyonlarını yeniden sunmak yoluyla önemli bir ideolojik etkide bulunur. Bu çerçevede van Dijk (2000: 34) New(s) Racism isimli makalesinde modern koşullar altında yeni bir ırkçılık türünün geliştiğini ve bu ırkçılık türünün metin ve konuşma üzerinden inşa edildiği için söylemsel olduğunu aktarmaktadır.

Toplumsal bilinçte yer edinmiş olan etnisite kaynaklı olaylarla ilgili olarak gelişen ideolojik, ayrıştırıcı ve ötekileştirici çerçevenin pek çok insanın günlük yaşantısında kendi kendine gelişmediği ve daha da önemlisi kitle iletişim araçlarının oluşturduğu söylemlerin bu konuda belirleyici bir rolü olduğuna vurgu yapılmaktadır (Van Dijk, 1991 :238). Bu doğrultuda toplumsal yapıda var olan grupların eşit olmadıkları gerçeği göz önüne alındığında, bu grupların medya içeriğine ulaşma ve medyada temsil edilebilme ve medya içeriğine etki edebilme gibi çeşitli konularda, toplumsal eşitsizlikten kaynaklanan farklı uygulamalara maruz kalmaları kaçınılmaz olmaktadır. Bu bağlamda söylemsel pratikler üzerinden gelişen ve van Dijk'ın da işaret etmiş olduğu bu yeni ırkçılık türünün kendini meşrulaştırdığı, yaygın hale getirdiği ve sıradanlaştırdığı yer de büyük oranda kitle iletişim araçları ve haber medyasıdır. Haber medyasının işleyişi ve haber kuruluşlarının işleyiş özellikleri, haber çerçevelerinin oluşumunu belirlemekte; uzlaşıyla oluşturulan bu çerçeveler ise toplumsal anlamın dolaşımını sınırlandırmakta ve sonuç olarak bu sınırlandırılmış anlamlar toplumsal gerçekliğin inşasına yol açmaktadır (Dursun, 2004: 43). Dolayısıyla haber, görselliğe ve metne dayanarak gerçekliğini kurarken, izleyiciye 'gördüğüne ve duyduğuna inan' emrini verir. Irkçı, ayrıştırıcı ve ötekileştirici bir bağlamda sunulan bu üst söylemin önünde ise anlatıcının sözünde belli 'doğruların' dikte edilmesi devam etmektedir (İnal, 1996: 107).

Bu bağlamda haber medyasının rolü; belirlenmiş bir toplumsal gerçekliği, söylem ve temsil yoluyla yeniden üretmek olarak belirlenmiştir. Çünkü haberde ele alınan içerik, toplumsal yapıda var olan egemen bakış açısına göre oluşmakta ve çerçevelenmektedir. Bu durumda haber medyasının ayrıştırıcı ve ötekileştirici bir tanımlayan pozisyonunda işlerlik kazandığı gözlerden kaçırılmamalıdır. Çünkü haber medyası ve haberin söyleminin toplumsal yapıya egemen olan örgütlenmelerden, yani güç/iktidar sahibi kurum ve kuruluşların söylemlerinden bağımsız olması mümkün değildir (İnal, 1996: 97). Haberin çerçevesini oluşturan bu unsurlar, belirli bir yaklaşım etrafında bir araya getirildiğinde, haberi alımlayan hedef kitlenin zihninde habere veya haberde yer alan olaya ilişkin beklenen ve istenen bir etki bırakılır. Bu nedenle haber, çoğu zaman gerçekliğe ilişkin bir inşa sürecini içerisinde barındırır. Bu inşa süreci ise büyük oranda kitle iletişim araçlarının ideolojik yönelimlerinin etkisi altındadır(Göker ve Keskin, 2015: 234).

Azınlıkların, yoksulların, göçmenlerin ve toplumsal yapıdaki diğer dezavantajlı gruplar; bazen kendilerinin de konu olabildiği haber medyasının içeriğinin oluşturulma süreçlerine ya da oluşturulan içeriğe etki etme gibi aşamalarda yetersiz kalmaktadır. Bunun yanı sıra bu dezavantajı grupların haber medyasına kaynak sağlayan temel söylem kaynakları olan politikacılar, sanatçılar, toplumsal elitler gibi gruplar arasında da yer almıyor olması, onları haber medyasında üretilen söylemleri sadece tüketen ya da bu söylemlere maruz kişilere dönüştürmektedir. Bu bakımdan grup üyeleri ile diğer gruplar arasındaki sınırlar, ideolojik temsiller neticesinde belirginleştirilir. Bireylere "biz" ve "öteki" bilinci bu şekilde aşılanır. Bu süreç, söylemin yaygınlaşmaşına ve tanımlayıcı temsillerin egemen bir bakış açısına dönüşmesine neden olmaktadır (van Dijk, 2003: 13). 
Büyük haber örgütlenmeleri üzerinden konu ele alındığında; araç, konu, çıktı, içerik ve politik olarak bu örgütlenmelerin birbirlerinden farklılaşmasına rağmen haber medyasının sık sık yabancı düşmanı ya da ırkçı söylemleri dolaşıma soktuğu, fakat kendisini de çok kültürlü ve çoğulcu olarak gösterdiği unutulmamalıdır. Bu anlatıma paralel olarak Hackett $(2005,92)$ da büyük haber örgütlenmelerinin birçok yönden demokratik eşitliğe ve bilinçli katılımcı yurttaşı̆ga karşıt olduğunu dile getirmektedir. Hall'e (2001) göre bugün haber medyasının içeriğini oluştururken kullanmakta olduğu haber değerleri; gerçekleri veya olayları sunmaktan ziyade güç sahipleri tarafından uluslararası haber medyasında toplumsal rızanın oluşturulması için örtülü olarak tasarlanmış veya oluşturulmuştur. Bu ifadeyi destekleyen Tuchman (1978: 196) da hâkim sınıfın ifadelerinin veya tanımlarının, haber medyası tarafından toplumsal bilince kolayca dağıtılabileceğini ve bunun haberin egemen sınıf ideolojisinden etkilenmiş yeniden kurulmuş bir kurgusu olduğunun ispatı olacağını söylemektedir. Ayrıca o bu nedenle haberin, sosyal kurumlarda hem sosyal anlamları hem de sosyal süreçleri yeniden yapılandıracağını dile getirir.

Bu bağlamda Simon Cottle (2000: 5) van Dijk'ın yeni ırkçılık dediği sürecin ortaya çıkardığı kamusal dil ve söylemin sürekli olarak göçmenleri, göçmen işçileri, mültecileri, iltica talebinde bulunanları ve etnik azınlıkları hayatın geleneksel yönüne ait olmayan kültürel yabancılar olarak gösterdiğini ifade eder. Benzer şekilde haber medyasının kullanmış olduğu sınırlı tanımlama repertuvarı nedeniyle, medya toplumsal yapıdaki ırk tanımlamasını yeniden yapmakta ve azınlıkları bu sınırlı tanımlama aralığı üzerinden ele alarak yansıtmayı tercih etmektedir (Matheson, 2005: 143). Özellikle mülteciler gibi toplumsal yaşamın "yok hükmünde" yer alan toplumsal gruplar açısından durum değerlendirildiğinde, ayırıcı ve tanımlayıcı farkılıkların, söylemin hemen hemen tüm katmanlarında belirginleştiği görülmektedir. Çünkü mülteciler, birer yabancı olarak değerlendirilir ve bu başlı başına bir "ötekilik” konumu sunmaktadır (Göker ve Keskin, 2015:236).

\section{Yöntem}

$\mathrm{Bu}$ çalışmada Teun van Dijk tarafından geliştirilmiş olan eleştirel söylem analizi yöntemi kullanılmıştır. Bu noktada eleştirel söylem analizi, haber içeriklerinde yer alan söylemlerdeki egemen ideolojik anlamlar ve bu anlamların hangi güç odaklarının lehine işlediğini açığa çıkarmaya olanak sağlamakta ve sosyal problemleri ele almaktadır. Eleştirel söylem analizini medya metinlerine uygulayan ilk bilim insanlarından Teun A. van Dijk, çalışmalarının büyük bir kısmında 1980'ler sonrası Avrupası'nda üretilen ırkçılık ve ön yargı konularına odaklanmaktadır. Teun van Dijk yaptığı çalışmalarda nitel ve nicel analiz tekniklerini de kullanarak Almanya, Hollanda ve İngiliz basınından örneklerle toplumun entelektüel kesimi sayılan gazetecilerin toplumda var olan etnik ön yargıların yanında, ötekileştirmeyi, nefreti ve ırkçılığı üretmede ne kadar etkili olduğunu kanıtlamaya çalışmıştır (Sözen, 1999: 124). Teun van Dijk'a (1993: 251252) göre eleştirel söylem analizi, toplumsal ve siyasi içerikli konuşmalar ve metinlerin öne sürdüğü ve yeniden ürettiği; eşitsiz, egemen ve istismar eden sosyal tahakküm yollarını araştıran söylem araştırmalarının bir türüdür. Bu kapsamda eleştirel söylem analizi özel bir yöntem, spesifik bir paradigma, bir ekol ya da bir okul oluşturma çabası içerisinde değildir. Bunun yerine toplumsal yapıda meydana gelen olayları söylemsel boyutta daha iyi bir şekilde ele alma ve analiz etme konularıyla ilgilenmektedir. 
Teun van Dijk (2008: 7-8) ayrıca eleştirel söylem çözümlemesinin; dilin kullanımı, söylem ve iktidara karşı sosyo-politik ve eleştirel bir yaklaşım olarak 1970'li yılların sonlarında bir grup eleştirel dilbilimcinin çalışmalarıyla başladığını ve 1980'ler ve 1990'lardan sonra eleştirel yaklaşımların yükselişe geçmesiyle uluslararası bir boyut kazandığını dile getirmektedir. Benzer şekilde Fairclough (1993: 135) da eleştirel söylem analizi yöntemiyle; söylemsel pratikler, olaylar ve metinler ile daha geniş kapsamda sosyal ve kültürel yapılar, ilişkiler ve süreçlerin ve bu süreçlerin bir sonucu olarak ortaya çıkan uygulamaların, olayların ve metinlerin iktidar mücadelesinin ortaya çıkardığı ilişkilere uygun biçimde ideolojik olarak nasıl şekillendirildiğinin analiz edilmesi olduğunu dile getirmiştir. Bu sayede toplumsal yapıdaki iktidar yapısı ve hegemonyanın devamını sağlayan toplum ve söylem arasındaki örtük ilişkiler görünür kılınmaktadır.

Teun van Dijk, 1980'ler sonrasında Avrupa ülkelerinde medyada mülteci, göçmen ve azınlıkların basında temsil ve tasvir edilme biçimini sorunsallaştıran çalışmaları sonucunda; etnik azınlıkların, göçmenlerin ya da mültecilerin basında yasadışılık, suç, saldırganlık, şiddet gibi olaylarla ilişkili olarak 'arsız, agresif, tehditkâr' tipler olarak temsil ve tasvir edildiğini dile getirmiştir. Öte taraftan bu olumsuzluk üzerine kurgulanmış olan 'öteki-sunumu' sistematik olarak olumsuz 'özsunumla', yani kendi kendini hoşgörülü, ırkçı olmayan, anlayışlı yurttaş olarak sunarak dengelenmektedir (Dijk, 2005: 337-338).

Bu türden olumsuz tasvirlerde 'bizim normlarımız, amaçlarımız, uzmanlığımız ya da kültürümüzle karşılaştırıldığında 'yetersiz' ya da 'geri' oldukları varsayılmakta'; göçmenlerin konut ve istihdam alanında yarattığı rekabet ele alınmakta ve 'bizim değerli kaynaklarımızı tehdit eden insanlar' olarak temsil edilmektedirler. Teun van Dijk, (2003: 80-81) mültecilere ilişkin Avrupa medyasında yer alan tanımlayıcı söylem biçimlerini kategorize ettiği çalışmasında, göçmenlerin medya içeriğindeki temsiliyle ilgili genel ideolojik stratejinin kendini olumlu ve ötekini olumsuz olarak sunma şeklinde gerçekleştirildiğini aktarmaktadır. Bu stratejinin geliştirilen söylemsel çerçevesinin geleneksel teması 'yük' olma durumudur. Başka bir deyişle göç ve göçmen karşıtı ideolojiler 'ötekilerin' bizim içim mali bir yük olduğunu vurgulamak suretiyle söylemde ifade edilebilir. Unutulmamalıdır ki, yük-teması göçmenleri ne ten renkleri ne kültürel farklılıklar ne de diğer önyargılardan dolayı değil, sadece ve sadece bunu 'yapamayacağımızı' ima ettiği için haber söylemindeki en 'güvenli' göç-karşıtı strateji olarak dikkat çekmektedir. Eleştirel söylem çözümlemesi kapsamında ele edilen bulguların sistematize edilebilmesi için Teun van Dijk'ın (1993: 264) önermiş oldu sınıflandırma başlıkları bu çalışmada kullanılacaktır. Bu başlıklar:

(a) Yargılama (Gerçeklerden Kaynaklanarak Olumsuz Değerlendirmeler Yapma)

(b) Retorik Görünüm (Olumlu Davranışların Gizlenmesi-Olumsuz Davranışların Ön Plana Çıkarılması)

(c) Lexical Stil (Negatifliği ya da Pozitifliği İma Eden Kelime Tercihleri)

(d) Hikayeleştirme: (Yaşanılan Olumsuzlukları Kişisel Deneyimlere İndirgeme)

(e) Olumsuz Davranışların Yapısal Vurgusu: (Başlıkta, Spotta, Ara Başlıkta, Girişte, Diğerine Ait Olumsuz Davranışlara Yer Verme).

(f) Güvenilir Kaynaklardan Alıntı Yapma 
Bu çalışmada mültecilerin Türk yazılı basınında tehdit unsuru ve öteki olarak nasıl temsil edildiği analiz edilmiştir. Medyada üretilen söylemler dikkate alınarak yazııı basında yayınlanan haberlerdeki ötekileştirici ve ayrıştırıcı söylemleri ortaya çıkarmak amaçlanmıştır. Çalışma kapsamında Türkiye özelinde hem tirajları hem de ana akım gazeteler olarak tanımlanmış olmaları nedeniyle Hürriyet, Milliyet ve Sabah gazeteleri örneklem olarak seçilmiştir. Ayrıca bu gazetelerin kitle gazetesi olması ve belirgin bir şekilde ideolojik bir eğilim taşımıyor olması; gazetelerin örneklem olarak seçilmesinde etkili olmuştur. Çalışmanın zaman aralığı Suriyeli mültecilerin Türkiye'ye geldikleri 2011 yılından başlayarak, 2017 yılına kadar olan zaman dilimini kapsamaktadır. Bu çerçevede örneklem için seçilen gazetelerde 2011-2017 yılları arasında Suriyeli mültecileri konu edinerek yayınlanan haberler analize tabi tutulmuştur. Analiz edilen haberler için çeşitli kütüphanelerde bulunan basılı gazete arşivlerinden yararlanılmıştır. Analiz edilecek haberler düşünüldüğünde geniş bir zaman aralığı olmasına rağmen Suriyeli mültecilerin ötekileştirilmesi sorunsalı odak noktası kabul edilmiştir. Bu sorunsala uygun olarak gazetelerin manşetlerinde yer bulan haberler ele alınarak, toplamda tespit edilmiş olan 143 haberden 71 haber analiz edilmeye uygun görülmüştür. Analiz edilen haberlerde Suriyeli mültecilerin toplumsal eşitsizlikler ekseninde nasıl ötekileştirildiği, bu süreçteki temsillerinin nasıl yapıldığı, hangi olay ve sorunlar etrafında bu temsillerin konumlandırıldığı, hangi sözcüklerle ve ifadelerle nasıl tanımlandığı gibi çeşitli sınıflandırmalar ve ayrıştırmalar saptanmaya çalışılmıştır.

\section{Bulgular}

\section{(a) Yargılama (Gerçeklerden Kaynaklanarak Olumsuz Değerlendirmeler Yapma)}

Bu grupta analiz edilen haberlerde, Suriyeli mültecilerin sebep olduğu gerçek durumlar üzerinden yargılayıcı ve ayrıştırıcı bir söylemin inşa edildiği bulgulanmıştır.

'Ayvalık'ta 20 Suriyeli kaçak yakalandı' (Hürriyet, 29.07.2014) başlıklı haberde Yunanistan'a kaçak yollardan geçmek isteyen mültecilerin yakalanması haberleştirilmiştir. Haberde mültecilerin Suriyeli oldukları haber başlığında özellikle belirtilerek, haber söyleminde Suriyeli mülteciler "kaçak" zamiri ile tanımlanmıştır. Bu tanımlama haberin genel söylemsel çerçevesinde Suriyeli mültecileri yasa dışı olmakla ilişkilendirirken, örtük olarak mültecilerin öteki bağlamına oturtulmasını sağlamıştır.

'Kilis'te kaçak sigaraya tutuklama' (Hürriyet,15.07.2014) başlığıyla yayınlanan haber metninde ise 5 kişinin karıştığı ve içlerinden birinin Suriyeli mülteci olduğu kaçak sigara operasyonu ile ilgili haberde; suçu işleyen diğer faillerin uyruklarından bahsedilmezken, mültecinin "Suriyeli" olduğu haberin spotunda ve metin içerisinde birkaç kez tekrar edilmiștir. Bu haberde de Suriyeli mültecilerin yasa dışı olmakla ilişkilendirildiği genelleyici bir söylemin inşa edildiği görülmektedir. Bu bağlamda haber söyleminde yargılayacı bir anlatının oluşması sağlanmış ve Suriyeli mülteciler ayrıştırıcı bir tanımlama sürecine tabi tutulmuşlardır.

'Zabıtadan Suriyelilerin iş yerlerine denetim' (Hürriyet, 29.05.2017) başlıklı haberde ise Islahiye'de Suriyeli mültecilerin işletmekte olduğu işyerlerine zabıta ekipleri tarafından yapılan denetim haberleştirilmiştir. Haberin başlığında denetimin özellikle Suriyeli mültecilerin işletmiş olduğu işletmelerde gerçekleştirildiği belirtilerek, yerli esnaftan ayrıştırılan ve ötekileştirilen bir Suriyeli söz konusu olmuş ve bu sayede ayrıştırıcı- 
ötekileştirici bir söylemin anlatı çatısı inşa edilmiştir. Haber metninde ise Suriyeli mültecilerin işletmekte olduğu işyerlerinde yapılan denetimler sonucunda bulunan ürünleri tanımlamak için "menşei belli olmayan", "sağlık koşullarını taşımayan", "son tüketim tarihi geçmiş" ve "halk sağlığına zarar verici" gibi ifadeler kullanılmıştır. Bu ifadeler üzerinden Suriyeli işletmecilerle ilgili olarak "sağlıksız", "zarar verici" ve "güvenilmez" gibi olumsuz düşüncelerin haber söyleminde ön plana çıkarıldığı görülmektedir.

'Suriyelilerin ruhsatsız sağlık merkezine baskın' (Hürriyet,19.01.2017) başlıklı haberde ise Gaziantepte Suriyeli mülteciler tarafından işletildiği öne sürülen bir sağlık merkezine yapılan baskın haberleştirilmiştir. Haber başlığında baskın ifadesinin kullanılması, Suriyeli mültecilerin suçla ilişkili olduğu düşüncesini meşrulaştıran bir anlatının oluşmasını mümkün kılmıştır. Haber metninde ise sağlık merkezinin izinsiz ve ruhsatsız olduğu vurgulanırken, sağlık merkezinin steril olmadığı özellikle ara başlıkta ve metinde geniş çapta yer bulmuştur. Bu tanımlama haber söyleminde Suriyeli mülteciler için "sağlıksız olan" ve "temiz olmayan" düşüncesini meşrulaştırarak, onları ayrıştırıcı bir tanımlama sürecine tabi tutmuştur.

'Izmirli işçilerden kaçak Suriyeli işçi tepkisi' (Hürriyet, 22.05.2013) başlıklı haberde ise İzmir'de işçi olarak çalıştırılan Suriyeli mültecilerin durumu haberleştirilmiştir. Haber söyleminde kaçak olarak çalıştırılmalarına sık sık vurgu yapılmaktadır. Bu vurgulamanın sebebi ise ucuz işgücü olarak görülmeleridir. Fakat haberlerde, onları bu şekilde gören ve kaçak olarak çalıştıranlar ön plana çıkarılmazken ya da sorumlu tutulmazken, haber söyleminde Suriyeli sığınmacıların ücretli çalışanlar için ekonomik bir sorunun kaynağı olduğu düşüncesi meşrulaştırılmıştır. Bu bağlamda haber ardalan-bağlam bilgisinden yoksun bir şekilde kurgulanmıştır. Haberde çalışma izinleri olmayan, fakat çalışmak zorunda olan, ucuz emek gücü olarak tercih edilen Suriyelilerin durumlarına değinmek yerine, kaçak sıfatı ile bundan sorumlu tutulanlar Suriyeli mülteciler olarak ön plana çıkarılmıştır. Haber söyleminde ayakkabıcılar odası başkanının "... emniyetimize bildirdik, eğer yabancı işçi çalıştırılıyorsa bunun gereği yapılır” sözleri ön plana çıkarılarak, yabancı düşmanlığı meşru bir zemine taşınmıştır.

'Insan taciri Suriyeli mülteciler tutuklandı' (Sabah, 28.05.2017) başlıklı haberde, Avrupa ülkelerine kaçak yollardan insan götüren bir suç örgütüne yapılan baskın haberleştirilmiştir. Haberde, göçmen kaçakçılığı yapan Suriyelilerin oluşturduğu bir kaçakçılık şebekesinin çökertildiğine dikkat çekilmek istenmiştir. Suç örgütü içerisinde birçok farklı etnik kökenden insan bulunmasına rağmen, haber başlığında ve metninde insan tacirlerinin Suriyeli olduğu vurgusu ön plana çıkarılmıştır. Bu bağlamda oluşan haber söyleminde, Suriyeli mültecilerin suçla ilişkilendirildiği ve öteki bağlamında sunulduğu görülmektedir.

'Hatay'da Suriye Hareketliliği' (Hürriyet, 05.09.2011) başlıklı haberde, Suriyelilerin düzenlemiş olduğu bir gösteri haberleştirilmiştir. Haber söyleminde, 'hareketlilik' kelimesi kaosa karşılık gelen bir anlatı çerçevesinde sunulmuştur. Haberde Suriyelilerin Türkiye'ye kaçak olarak geçmek istediği, bu durumun resmi olarak engellenmesi sonucunda ise Türkiye'de çadır kentte bulunan Suriyelilerin protesto yaptığı anlatılmaktadır. Bu bağlamda haber söyleminde Suriyeli sığınmacılar olay çıkaran, sorun oluşturanlar olarak gösterilir. Bu haberin 'Suriyeliler Türkiye sınırına akın etti' şeklindeki alt başlığında kullanılan ‘akın' kelimesi ise bir tehdide karşılık gelmektedir. 
Bu bağlamda Suriyeli mültecilerin tehdit unsuru olarak sunulması, öteki bağlamında haber söyleminde meşrulaşmasına da neden olmuştur.

11.05.2015 tarihinde Hürriyet Gazetesi'nde yayınlanan, 'İstanbul'da Suriyeli Savaşı' başlıklı haberin spotu: 'Savaştan Türkiye'ye kaçan Suriyelilerle ilgili rahatsızlık, İstanbul'da faciaya dönüyordu. Güvercintepe'de bir çocuk bıçaklanınca mahalleli ayaklandı, Suriyeliler'e ait dükkânlar kurşunlandı, ateşe verildi.' Gibi ifadeler içermektedir. Bu haberde yerli halkın Suriyeli sığınmacılardan duyduğu rahatsızlık herkese iletilirken, 'facia', 'ayaklanma', 'kurşunlama' ve 'ateşe verme' gibi kaos ortamını çağrıştıran kelime ve tanımlamalar kullanılarak sı̆̆ınmacılar 'çatışma yaratan', 'çatışmaya sebep olan' ve 'öteki' şeklinde çerçevelenmiştir. 25.02.2012 tarihli Milliyet Gazetesi'nin 'Hatay sokaklarında 'karanlık' misafirler!' başlıklı haberinin 'Hatay sokaklarında tedirginlik hakim. Hataylılar, gelenlerin olay çıkardığını, lokantalarda hesap ödemediğini iddia ediyor. Hatta tiplerinden ve kaba hareketlerinden dolayı onların EI Kaide militanı bile olduğunu söyleyen var...' spotunda, Hatay sokaklarının tedirginliği, hesap ödemeyen, kaba tipler, El Kaide militanına benzetme gibi durumlar nedeniyle, Suriyeli sığınmacıların hepsine ön yargıyla yaklaşılmasını ve onların tehlikeli bir 'öteki' olarak konumlandırılmasını beraberinde getirmektedir.

(b) Retorik Görünüm (Olumlu Davranışların Gizlenmesi-Olumsuz Davranışların Ön Plana Çıkarılması)

'200 bin Suriyeli sokakta kaldı' (Hürriyet,11.07.2014) başlıklı haberde Türkiye’ye sığınan Suriyeli mültecilerden büyük bir kısmının sokaklarda yaşadığı haberleştirilmiştir. Haber metninde bu durumun sosyal hayatı olumsuz etkilediği ön plana çıkarılarak, Suriyeli mültecilerin sosyal sorunların sebebi olduğunu pekiştiren bir anlatı yapısı oluşturulmuştur. Bu yapıyı ötekileştirici bir bağlama taşıma içinse "Suriyelilerin, hırsızlık, dolandırıcılık ve yankesicilik gibi suçlara yönelerek kendi aralarında çeteler kurduğu" ifadesi hem ara başlıkta hem de haber metninde sık sık tekrar edilmiştir. Haberde, 'Suç oranları hızla artıyor' adlı alt başlığı sayesinde Suriyelilerin sayısının artmasının, kentteki suç oranlarının artışıyla doğru orantılı olduğu iması da ötekileştirici bir söylemin oluşmasına neden olmuştur. Bu bağlamda haber metninde Suriyeli mülteciler için olumsuzluklar barındıran anlatımların ön plana çıkarıldığı ve onları "sorunlara sebep olma" ve "suçla ilişkili olma" düşüncesi ile ilişkilendiren söylem de meşrulaştırılmıştır.

'Hatay sokaklarında 'karanlık' misafirler' (Milliyet,25.02.2012) başıklı haberde Suriyeli mültecilerin tehlikeye sebep olan bir tanımlama üzerinden aktarıldığı görülmektedir. 'Karanlık misafir' anlatısı ise haber söyleminde açık bir şekilde Suriyeli mültecileri ötekileştirirken; onların tedirginliğe sebep olan, belirsizlik içeren ve yabancı olan şeklinde tanımlanmasına neden olmuştur. 'Parklar, Suriyelilerin zaman geçirme mekânı oldu' (Milliyet, 22.09.2014) bağlığıyla yayınlanan haberde, özellikle 'Suriyeli' vurgusunun ön plana çıkarıldığı görülmektedir. Ayrıca her iki haberin başlıklarında kullanılan 'karanlık misafir' ve 'mülteci' tanımlamaları haber söyleminde Suriyeli mültecilerin bilinmezlik ve sorun düşüncesi ile ilişkilendirilmesine neden olmuştur. Bu tanımlamalar Suriyelilerin haber söyleminde öteki olarak inşasına zemin hazırlayan bir anlatıyı da normalleştirmiştir. Ayrıca Suriyelilerin kentin görüntüsünü bozan, kentte istenmeyen bir görüntünün oluşmasına sebep olan, parkları işgal eden gibi imalarla metne yerleştirilmiş olması, haber söylemlerinde üretilmek istenen 'öteki' söylemini pekiştirmiştir. 
'AŞTi 'açık otel'e döndü' (Hürriyet,15.07.2014) ve 'Roma Tiyatrosu'na 'mülteci' çadırı' (Hürriyet,17.07.2014) başlıklı haberlerde Suriyeli mültecilerin kamusal ve kültürel alanlardan olan Ankara Şehirlerarası Otobüs Terminali'ni ve Ankara Ulus'taki tarihi Roma Tiyatrosu kalıntılarını barınma yeri olarak kullandıkları haberleştirilmiştir. Burada da bir barınma sorununa dikkat çekilerek, Suriyelilerin olumsuz yaşam koşulları ve çevrede bıraktıkları olumsuz etkiler haber söyleminde yinelenmek istenmiştir. AŞTi'de konaklayan Suriyeli mültecilerin "yolcuları rahatsız ettikleri", "dilendikleri", "çevreyi kirlettikleri" ve "kötü bir görselliğe sebep oldukları" gibi ayrıştırıcı ve ötekileştirici tanımlamalara sık sık yer verilmiştir. 'Roma Tiyatrosu'na 'mülteci' çadırı' başıı̆ı ile yayınlanan haberde, önemli bir tarihi kalıntısının 'mülteci'ler tarafından kirletildiği ve mültecilerin tarihi dokuya zarar verdiği düşüncesi meşrulaştırılmıştır. Bu bağlamda haber başlıkları üzerinden inşa edilen söylemlerde Suriyeliler, korku uyandıran, kaba hareketler sergileyen, uzun sakallı kişiler olarak betimlenirken, Suriyeli mültecilerin sebep olduğu olumsuz davranışlar haber söyleminde ön plana çıkarılmıştır.

Hürriyet gazetesinde 'Suriye Kaldırımı' (Hürriyet,18.07.2014) ve 'Köprü manzaralı 'mülteci' kondu' (Hürriyet,25.07.2014) başlıklı haberlerde de benzer durumları görmek mümkündür. 'Suriye Kaldırımı' tanımlaması, Suriyelilere ait bir yeri işaret etmekle birlikte, kaldırımların işgal edildiği imasını da haber söyleminde ön plana çıkarmaktadır. Bu bağlamda haber söyleminde olumsuzluğun ön plana çıkarıldığı ve sorumlusunun da Suriyeli mülteciler olduğu düşüncesi işlenmiştir. "Mülteci' kondu', şeklinde oluşturulan kelime kalıbı, çarpık kentleşmeye sebep olan bir gece kondu benzetmesi şeklinde ifade edilmiştir. Bu tanımlama sürecinde de Suriyeli mültecilerin sebep olduğu "birçok sorundan" farklı olarak, Türkiye'deki çarpık kentleşmenin de sorumlusu olarak sunulduğu bir haber söylemi dolaşıma sokulmuştur. Bu bağlamda uzun yıllardır çarpık kentleşme sonunu yaşayan bir ülke olarak Türkiye bilgisi haber metninde gizlenirken, Suriyeli mülteciler çarpık kentleşmenin sorumlusu olarak sunulmuştur.

\section{(c) Lexical Stil (Negatifliği ya da Pozitifliği İma Eden Kelime Tercihleri)}

Bu grupta analiz edilen haberlerde, Suriyeli mültecilerin tanımlanmasında kullanılan kelime tercihlerinin negatiflik barındıran ve bu negatiflikle Suriyeli mültecileri ilişkilendiren bir yaklaşım sonucu oluştuğu gözlemlenmiştir. Bu nedenle haberlerde sık sık kullanılarak haber söylemini genel bir çerçeve üzerine inşa etme sürecindeki kelime tercihlerine odaklanılmıştır.

'Fikirtepe'ye Suriyeli mülteci akını' (Hürriyet, 27.07.2014), 'Türkiye'ye gelen Suriyeli sayısı 11 bini aştı' (Milliyet, 26.06.2011), '15 bin Suriyeli sınıra dayandı' (Milliyet, 12.06.2011), 'Korkulan oldu...173 Suriyeli Türkiye’ye sığındı' (Milliyet, 08.06.2011), 'Mülteci akını kitlesel göçe dönüştü' (Milliyet, 14.10.2012), 'İzmir'de harmandalı paniği' (Milliyet, 28.08.2012), 'Büyük göç yolda' (Milliyet, 16.08.2012), 'Suriye'den gelmesi beklenen 'göç' dalgası' (Milliyet, 13.11.2014), 'Fikirtepe'ye Suriyeli mülteci akını' (Sabah, 27.06.2014), 'Sınıra Suriyeli akını sürüyor' (Sabah, 22.09.2014), 'Suriyeliler İstanbul'a akın ediyor' (Milliyet, 30.10.2013) başlıklı haberlerde yapılmış olan kelime tercihleri haber söylemlerinin belirli bir doğrultuda şekillenmesine neden olmuştur. Özellikle Suriyeli mültecilerin Türkiye'ye girişi, 'dalga' ve 'akın' gibi metaforlarla aktarılmaktadır. Bu haberlerin neredeyse hepsinin başlıklarında ve ara başlıklarında görüldüğü gibi, Suriyeli mültecilerin "büyük gruplar halinde", "akın" ya da "dalga" şeklinde gelmekte olduğu vurgulanmıştır. Bu kelimelerin ve tanımlamaların tercih 
edilmesi; haber söyleminde Suriyeli mültecilerin tehdit olarak algılanmasını, istilacı olarak düşünülmesini ve öteki pozisyonuna yerleştirilmelerini kolaylaştırmıştır. Aynı şekilde 'korkulan oldu' şeklindeki bir anlatının hem başlık hem de haber metninde sık sık kullanılmış olması, sığınmacıların tehlike içeren durumların sebebi olduğu fikrini kuvvetlendirmiştir. Sınırdan ülkeye giriş yapan mültecilerin sayılarının çokluğunu anlatmak için kullanılan metaforlardan "dalga", yıkıcı olmaya; "akın" ise bir saldırıya, istilaya ya da işgale karşılık gelmektedir. Haber metinlerinde bu kelimelerin tercih edilmesi, Suriyeli mültecilerin Türkiye yönelik açık bir tehdit olarak algılanmasını kolaylaştırmış ve haber söylemlerinde 'öteki' olarak kabul edilmesi gerektiği düşüncesi örtük olarak meşrulaştırılmıştır. Burada dikkat çeken konu, mültecilerin ülkeye girişi birçok haberde ısrarlı bir şekilde "tehdit" iması ile ilişkilendirilerek verilmiştir. Suriyeli mültecilerin Türkiye'ye geliş haberi her seferinde rakamlarla birlikte verilerek, haber söylemi istatistiki veriler üzerinden inandırıcı bir bağlama çekilmiştir. Haberlerde Suriye'deki savaşın geldiği boyut ve savaş mağduru mültecilerin sayısının neden arttığı değil de, sayıları artan şekilde Türkiye'ye gelişleri, toplumsal sorunlara sebep olmaları, masraf olarak nitelendirilmeleri de yapılan kelime tercihleri aracılığıyla ön plana çıkarılmıştır.

Haberlerde kullanılan 'sığınmacı trafiği' kelimesi 'kaotik bir sürece' gönderme yapmaktadır. Trafik kelimesinin yarattığı karmaşa, trafiğin yol sistemini kilitlemesi, düzeni alt üst etmesi Suriyeli mültecilerin durumunu betimlemek için kullanılmıştır. 'İzmir'de harmandalı paniği' başlıklı haberin içeriğinde ise, 'İzmir'e sıçradı' ifadesinin kullanılması; yayılan bir soruna, bulaşıcı bir hastalığa ve yangın gibi bir doğal afete karşılık gelmesi, 'sıçradı' kelimesinin tercih edilmesi nedeniyle olumsuz bir söylemin Suriyeli mültecilerle ilişkilendirilmesine neden olmuştur. Bu bağlamda haber söyleminde Suriyeliler 'öteki' pozisyonunda konumlandırılarak sunulmuştur. 'Fikirtepe'ye Suriyeli mülteci akını' haberinin içeriğinde ise başlıkta kullanılan akın kelimesi, 'diğerlerini uyarıcı' bir anlatının haber metninde oluşmasına izin vermiştir. Aynı haberin söyleminde bir vatandaşın açıklaması olan 'Onların alışveriş yaptığı bakkaldan ekmek alamıyoruz', 'kendi çocuklarımız' ifadelerinin ön plana çıkarılması ile günlük hayatta Suriyelilerin zaten 'öteki' olarak konumlandırıldıklarını göstermektedir.

Haberlerde kullanılan cümleler, bu cümlelerin gramatik dizilişleri ve sentaksına bakıldığında 10.08.2012 tarihli Milliyet Gazetesi'nin, 'Suriyeliler, kimlik soran polisi tabancayla yaraladı' başlıklı haberinde 'Suriyeliler' ifadesi cümle başına çekilerek fail pozisyonuna yerleştirilmiş ve polisin yaralanması eylemi cümle sonuna atılmıştır. Yani yapılan eylemin ne olduğunu vurgulamak yerine 'yapanın kim olduğu' ve 'uyruğunun ne olduğu' vurgulanmak istenmiştir. Aynı durum İstanbul'da bir fast-food firmasının müdürünün müşterilerin yemek artıklarını toplayan Suriyeli mülteci çocuklardan birisine şiddet uygulaması Hürriyet Gazetesi 31.01.2015 tarihinde yayınlanan 'Patatesleri alan Halil'e vurduğum için pişmanım' başlıklı haberde ele alınmıştır. Haber metninde firma müdürünün duyduğu pişmanlık yerine çocuğun ismi, uyruğu, mülteci olma durumu ve yaptığı eylem ön plana çıkartılırken; haber söylemi çocuğun bir 'öteki' olduğu düşüncesini güçlendiren bir anlamsal çerçeve ile sınırlandırılmıştır. Bu haberdeki kaynak kullanımı da tek yönlü olmuş ve Suriyeli Halil'in ya da yakınlarının aktarımlarına yer verilmemiştir.

Suriyeli sığınmacıların kamplardaki ve barınma koşullarındaki yetersizlik nedeniyle sıkça salgın hastalıklara sebep olduğunu dile getiren haberler de yapılmıştır. 'Mülteciler 
5.5 milyon kez muayene oldu' (Milliyet, 07.10.2014), 'Adana'da korkutan hastalık' (Milliyet, 08.03.2015), 'Çocuk felcinde Suriyeli alarmı' (Hürriyet, 27.05.2014) başlıkı haberlerde; Suriyelilerin yerli halkın sağlığı üzerinde tehdit oluşturan bir 'yabancı' ya da 'öteki' olduğu anlatısına dair vurgular sık sık yapılmıştır. Bu tür haberler, Suriyelilerle bir arada yaşayanların korkularını tetikte tutacak şekilde sunulmuştur. Örneğin "Çocuk felcinde Suriyeli alarmı" haberinde kullanılan 'alarm' kelimesi ve 'Adana'da korkutan hastalık' haberinde kullanılan 'korku' kelimesinin tercih edilmesi ile Suriyelilerin varlığı Türkiye vatandaşlarının can ve mal güvenliklerine bir tehdit olarak işaretlenmiştir.

(d) Hikayeleştirme: (Yaşanılan Olumsuzlukları Kişisel Deneyimlere İndirgeme)

'Başkent'te sonu gelmeyen kovalamaca' (Hürriyet, 06.07.2014) başlıklı haberde Suriyeli mültecilerin Ramazan ayında cami, türbe vb. yerlerde yoğun olarak dilencilik yaptığı bilgisi haberleştirilmiştir. Haber söyleminde bu mekandaki dilencilerin sadece Suriyeli olduğu fikri işlenmeye çalışılmıştır. Dilenci olarak tanımlanmanın öteki pozisyonuna yerleşme, ötekiliği kabul etme gibi süreçleri hızlandırdığı düşünüldüğünde, bu haberde dilencilik yapan Suriyeli mültecilerin kendi istekleri ile dilenciliğe devam ettikleri vurgulanmıştır. Zabıta görevlilerinin aktarımlarını haber söyleminde ön plana çıkaran gazete, Suriyeli mültecilerin kamplarda yaşamayı reddettikleri için dilencilik yaptıklarını ve ısrarı aşan bir şekilde hatta bazen zorla insanlardan para talep ettikleri düşüncesini meşrulaştırmak istemiştir. Bu bağlamda haberde dilencilik ve Suriyeli olma durumları arasında bir ilişki kurulmuş, haber metni bu doğrultuda anlamsal bir kapanmaya tabi tutulmuştur. Dilenciliğin bir Türkiye gerçeği olduğu metinde dile getirilmezken, Suriyeli mültecilerin dilenciliği kendilerinin tercih ettiği ön plana çıkarılmak istenmiştir. Zabıta ekiplerinin uğraşlarına rağmen, Suriyeli mültecilerin dilenciliği kendi istekleriyle sürdürdükleri vurgulanmıştır.

'Mülteciler camii nöbetinde' (Hürriyet, 22.04.2014) başlıklı haberde Suriyeli mültecilerin Türkiye'de toplumsal hayatta sebep oldukları dilencilik sorunu ele alınmıştır. Haber söyleminde Suriyeli mültecilerin dilencilik yapmalarının gerekçeleri "kolay para kazanma" ve dilenciliği "meslek edinme" olarak aktarılmıştır. Bu aktarım üzerinden haber söyleminde Suriyeli mültecilerin kendi istekleri ile dilenciliği tercih ettikleri, hikayesel bir anlatı üzerinden aktarılmıştır. Haber söyleminin geneline bakıldığında ise, Suriyeli mültecilerin, dilenerek ve dini duyguları sömürerek Türk halkından zorla para istediği ifade edilmiştir. Bu noktada Suriyeliler, huzuru bozan, dini duyguları sömüren, aldatıcı olan bir kategoride sunulmuş ve haber söylemlerinde 'öteki' pozisyonuna yerleştirilmiştir.

‘Günlüğü 10 lirayaçalışıyorlar'(Milliyet, 28.10.2012) başlıklı haberde, Kahramanmaraş’ta düşük ücretlerle inşaat sektöründe çalışan Suriyeli mülteciler haberleştirilmiştir. Haber başlığında kullanılan '10 liraya çalışıyorlar' ifadesi üzerinden Suriyeli mültecilerin yerli çalışanları işsiz bıraktığı vurgulanmak istenmiştir. Haberin hem spotunda hem de giriş ve ara başlıklarında benzer ifadeler yinelenerek, haber söyleminde üretilmek istenen Suriyeli mülteciler ve işsizlik düşüncesi güçlendirilmiştir. Bu haberin genel söylem çerçevelerinde; bu insanların göç etmesine sebep olan, onları yoksul hale getiren savaş görünmez kılınmıştır. Aynı zamanda onları bu ücretlerle çalıştıranlar da haber söyleminde görünmez kılınmıştır. Bu bağlamda haber söyleminde yaşanılan koşulların ve durumun sorumlusu olarak Suriyeli mültecilerin kendileri merkezi bir konuma yerleştirilmiştir. 
'Suriyeli dilenci operasyonu' (Milliyet, 09.12.2014) haberinde ise Adana'da şehirde trafik ışıklarında dilenen Suriyeli Mültecilerin toplanarak, mülteci kamplarına götürüldüğü haberleştirilmiştir. Haber söyleminde Suriyeli mültecilerin 'kolay para' nedeniyle dilenciliğe alıştıkları ifadesi dile getirilirken, zabıtaların sonu gelmeyen kovalamaca ile mülteci dilencilerle baş edemediği belirtilmektedir. Zabıta ekiplerince Suriyelilere operasyon düzenlendiği dile getirilen haberde; 'operasyon' kelimesinin kullanımı ile bir sorunu çözmek için yapılan baskın anlatılırken, Suriyeli mülteciler bu söylemsel çerçevede sorunun kaynağı konumuna yerleştirildiği de görülmüştür. Dilenci olmanın Suriyeli mültecilerin kendi istekleri olarak sunulan haber söyleminde, dilenci anlatısı aynı zamanda ayrıştıran ve öteki pozisyonuna yerleştiren bir bakış açısı üzerinden meşrulaştırılmıştır.

(e) Olumsuz Davranışların Yapısal Vurgusu: (Başlıkta, Spotta, Ara Başlıkta, Girişte, Diğerine Ait Olumsuz Davranışlara Yer Verme).

$\mathrm{Bu}$ grupta analiz edilen haberlerde, Suriyeli mültecilerin tanımlanmasında olumsuzlukların öncelendiği ve bu olumsuzlukların haber başlığında ya da haberin yapısal tasarımında ön planda ele alındığı görülmektedir. Özellikle Suriyeli mültecileri okuyucuya olumsuzluk kurgusu üzerinden servis eden haber tasarımlarının planlı bir yapı arz ettiği de gözlemlenmiştir. Bu planlama çerçevesinde genellikle ekonomik yapıyla ve suçla ilişkili haberlerin belirli başlıklar, spotlar, haber girişleri ve ara başlıklar üzerinden bütüncül bir kurguya maruz kaldığı görülmektedir.

'Bir yılda Osmaniye'de işsizlik oranı 4 puan arttı' (Hürriyet, 05.07.2014) başlıklı haberde Suriyeli mültecilerin kaçak ve ucuz olarak çalıştırılmasının, Osmaniyeli işçilerin işlerini kaybetmelerine sebep olduğu haber söyleminde ön plana çıkarılmıştır. Haberde söyleminde ısrarlı bir şekilde Suriyeli mültecilerin, Türkiye'deki varlığı ekonomik dengeleri alt üst eden bir sorun olarak tanımlanmaktadır. 'Bir yılda Osmaniye'de işsizlik oranı 4 puan arttı' haberinde Suriyelilerin kaçak ve ucuz olarak çalıştırılmasının, Osmaniyeli işçilerin işlerini kaybetmelerine sebep olduğundan söz edilirken, haber söyleminde Suriyeli mültecileri çalıştıran işverenler sorunsal olarak ön plana çıkarılmamaktadır. Haberin başlığında, spotunda, haber girişinde, ara başlıklarda ve haber metninde bütüncül bir şekilde işsizlik oranının sebebi olarak Suriyeli mülteciler işaret edilmiştir.

'Suriyeliler işsizliği artırıyor' (Hürriyet, 28.10.2016) başlıklı haberde benzer şekilde haber metninde Suriyeli mültecileri suçlayan bütüncül bir uyumluluğun olduğu görülmektedir. Haber başlığından, son paragrafa kadar; Suriyelilerin, Türk vatandaşının işsiz kalmasına sebep olduğu, ülke ekonomisini kötü etkilediği vurgusu yapılarak, Suriyeli mültecilerin ekonomik sorunların sebebi olduğu düşüncesi meşrulaştırılmıştır. Haber söylemi de bu bağlamda Suriyeli mültecilerin olumsuz bir anlatı çatısı üzerinden 'öteki' pozisyonuna yerleştirilmeleri sağlanmıştır.

'Suriyeliler akın etti kiralar \%30 yükseldi' (Milliyet, 15.12.2013), 'Suriyeliler kira ve emlak fiyatlarını uçurdu' (Milliyet, 06.09.2014), 'Suriyeliler gelecek evimden çık' (Milliyet, 27.10.2012) başlıklı haberlerde de benzer bir yapının oluşturulduğu görülmektedir. Haber metinlerinde bütüncül bir şekilde Suriyeli mültecilerin ev kiralarındaki artışın temel sorumlusu olduğu düşüncesi üretilmiştir. Bu çerçevede haber söylemlerinde sonradan gelenler olarak "öteki” pozisyonuna örtük şekilde yerleştirilen Suriyeli mültecilerin 
Türkiye'deki varlığı ekonomik dengeleri alt üst eden bir sorun olarak tanımlanmaktadır. 'Suriyeliler gelecek evimden çık' başlıklı haberde ev sahiplerinin Suriyelilere ev vermek için Türk vatandaşlarını evden çıkardığı anlatılarak, tüm sorumluluk Suriyeli mültecilere yüklenmiştir. Bu bağlamda günlük hayatta kiraların artışının sorumlusu da 'öteki' olarak konumlandırılan Suriyeliler olarak görülmektedir. Bu haberlerin üçünde de örtük olarak Suriye mülteciler ekonomik sıkıntıların sebebi olarak öne çıkarılmakta ve ekonomik bir masraf, yük olarak tanımlanmaktadır. Karın tokluğuna çalışan, yüksek kiralar ödeyen Suriyelilerin işletme ve ev sahipleri tarafından sömürülmeleri gerçeğinin üzeri ustaca kurgulanan haber söylemi sayesinde örtülmüştür.

‘Patronunun eşini öldürdü birlikte cesedi aradı' (Hürriyet, 23.07.2014) başlıklı haberde Alanya'da Suriyeli bir mülteci tarafından işlendiği iddia edilen cinayet konusu ele alınmıştır. Mahkemenin henüz karar vermemesine rağmen; haberin başlığında, spotunda, girişinde ve ara başlığında Suriyeli mültecinin suçlu olduğunu ve cinayeti işlediğini kesin olarak ifade eden tanımlamalara yer verilmiştir. Bu çerçevede haber metni ve haberde üretilmek istenen genel söylemsel çerçeve bütüncül bir şekilde, suçlayan bir anlatıyı oluşturmak için kurgulanmıştır. Bu bağlamda haberde Suriyeli mülteciler, Türk vatandaşlarının güvenliğini tehdit eden olumsuz failler olarak haber metinlerinde çerçevelenmektedir.

'Oturdukları evin sahibini öldürüp, parasını çaldılar' (Hürriyet, 16.04.2017) başlıklı haberde ise Adıyaman'da yaşan bir cinayet olayı haberleştirilmiştir. Haberde fail olarak tespit edilen Suriyeli iki mülteci hakkında detaylı bilgiye yer verilirken, hem spotunda hem de haber metninde sanıkların uyrukları özellikle vurgulanmıştır. Haberde Suriyeliler hem cinayet işleyen hem de hırsızlık yapan suç unsuru olarak nitelendirilmiştir. Bu bağlamda haberin detayında ve başlıkta Suriyeli mültecilerin öldürdükleri kişiyi soydukları da ön plana çıkarılarak, haber söyleminde genelleyici bir şekilde Suriyeli mültecilerin tehlikeli oldukları düşüncesi meşrulaştırılmıştır.

'Çocuğa işkence yapan Suriyeliler yakalandı' (Hürriyet, 25.04.2017) başlıklı haberde Şanlıurfa'da yaşanan bir olay haberleştirilmiştir. Haberde Suriyeli inşaat işçilerinin küçük bir çocuğa yönelik soyut ve somut şiddet uygulamaları aktarılmıştır. Haber söyleminde genelleyici bir bakış açısının var olduğu ve bu çerçevede genelleyici bir söylemin üretilmek istendiği görülmektedir. Haberin başlığı, spotu, haber girişi ve ara başlıklarında olayın sorumlularını tartışmak yerine, Suriyeli mültecileri tartıştıran bir anlatı çatısının inşa edildiği görülmektedir.

'3 Suriyeli çalıştıkları atölye sahibinin oğlunu öldürdü’ (Hürriyet, 07.05.2017) başlığıyla yayınlanan haberde Gaziantep’te meydana gelen adli bir olay ele alınmıştır. Haber metninde Suriyeli mültecilerin önce kendi aralarında kavga ettikleri aktarılırken, kavgayı ayırmaya çalışan atölye sahibinin oğlunu sonradan planlayarak öldürdükleri aktarılmaktadır. Haber söyleminde daha önceki haberlerde olduğu gibi bütüncül bir şekilde suça karışıldığı vurgulanmıştır. Atölye sahibinin oğlunu arkadaşları ile birlikte hareket ederek öldüren Suriyeli mülteciler organize bir suç örgütü şeklinde tanımlanmıştır. Daha önce de benzer olayların yaşandığının haber metninde tekrar edilmiş olması, haberde üretilmek istenen suç-Suriyeli mülteci ilişkisini kuvvetlendirmiştir. 
haberde, Hatay'da medyana gelen bir adli olay haberleştirilmiştir. Olayın kimlik kontrolü sonucunda çıktığının aktarııması sonrasında, haber söyleminde Suriyeli mülteciler eyleyen-fail pozisyonuna yerleştirilerek sunulmuştur. Silahla yaralamanın yanı sıra, kalabalık bir grubun diğer polis memurlarına saldırdığı bilgisine de haber metninde geniş çapta yer verilerek, Suriyeli mültecileri genelleyici bir şekilde 'saldırganlık' düșüncesi ile ilișkilendirmesi gerçekleşmiștir. Haberde bașlık, spot, giriș ve ara bașlık gibi farklı bölümlerde birbirini destekleyen unsurlara yer verilmesi, haber söyleminin bütüncül bir bakış açısı üzerinden üretilmesini de kolaylaştırmıştır.

'Suriyeliler bir kişiyi boğarak öldürdü' (Milliyet, 18.12.2015) başlığıyla yayınlanan haberde, Gaziantep'te işlenen bir cinayetin bilgisine yer verilmiştir. Cinayeti işleyenin kim olduğu henüz belli olmamasına rağmen, şüpheli olarak aranan iki Suriyeli mülteci yerine, hem haberin başlığında hem de spot ve haber girişinde "Suriyeliler" olarak genelleyici bir anlatıma yer verilmiştir. Bu anlatım üzerinden haber söyleminde Suriyeli mültecilerin suçla ilişkilendirmesi ve genelleyici bir bakış açısı ile tehlike-tehdit olarak sunulması sağlanmıştır.

'Suriyelilerin gürültü yapmayın cinayeti' (Milliyet, 16.05.2017) başlıklı haberde Mersin'de yaşanan ve cinayetle sonuçlanan bir kavga haberleştirilmiştir. Haber metninde evinin önünde gürültü yapan Suriyeli mültecileri uyardığı için öldürülen bir Türk vatandaşının hikayesine geniş çapta yer verilmiştir. Haber söyleminde 'Suriyelilerin 20 kişilik bir grupla bir kişiye saldırdığı', 'uyarıları dikkate almadıkları', 'kendilerine daha önce yardım eden birini öldürdükleri', ve 'benzer bir olayın yakın zaman önce de yaşandığı' gibi bilgiler verilerek haber söyleminde suçla ilişkilendirilmiş genelleyici bir Suriyeli mülteci algısı üretilmiştir. Ayrıca haber kurgusunda birbirini tamamlayan unsurların aynı söylemi üretmek için belirli bir mantıkla haber metnine yerleştirildiği de görülmektedir.

'Gaziantep’te Gerginlik' (Sabah, 13.08.2014) başlıklı haberde, bir trafik kazasına karışan Suriye plakalı otomobilin, bir aileye çarpması ve aracın 'Suriye plakalı' olduğu vurgusu üzerinden, tüm Suriyelilere dönük bir söylemsel çerçeve oluşturulmuştur. Haber kurgusunda bütüncül bir yaklaşımla haber söyleminde tüm Suriyelilerin bir yabancı, öteki olarak tehlike içerdiğine gönderme yapılmıştır. 'Tecavüz iddiası mahalleliyi ayağa kaldırdı' (Sabah, 25.08.2014), 'Kira isteyen ev sahibini öldürdü' (Sabah, 13.08.2014), 'Gaziantep'te tehlikeli gerginlik' (Hürriyet, 16.07.2014) başlıklı haberlerde, Suriyeli mültecilerin Türkiye'deki varlığının suçla ilişkilendirildiği görülmektedir. Suriyeli mülteciler, Türk vatandaşlarının güvenliğini tehdit eden olumsuz failler olarak haber metinlerinde çerçevelenmektedir. Bu haberlerin çoğunda Suriyeli mülteciler; dolandırıcı, hırsız, saldırgan, cinayet işleyen, tecavüzcü olarak tanımlanmaktadır. 'Haberde Türk kelimesinin kullanımı da biz ve öteki ayrımını belirginleştirir. 'Oturdukları evin sahibini öldürüp, parasını çaldılar' başlıklı haberde Suriyeliler hem cinayet işleyen hem de hırsızlık yapan suç unsuru olarak nitelendirilmiştir.

'Suriye tankları Türkiye sınırında' (Hürriyet, 09.06.2011), 'Türkiye-Suriye sınırından silah geçirilmeye çalışıldı' (Milliyet, 18.04.2011), '8 askerimizi şehit eden silahlar Suriye'den' (Milliyet, 06.08.2012), 'Niğde'yi alarma geçiren araç' (Sabah, 15.10.2014) başlıklı haberlerde, Suriyeli mültecilerin suçla ilişkili söylemler üzerinden aktarılması söz konusu olmuştur. 'Niğde'yi alarma geçiren araç' haberinde Niğde'de trafik ekiplerinin radar uygulamasından kaçan Suriye plakalı cipin, polisi şüphelendirdiğinden söz edilmiştir. Araba plakasının Suriye'ye ait olması, tehdit içeren bir durum olarak 
gösterilmektedir. Suriye tanklarının Türkiye sınırında olması, Türkiye-Suriye sınııından silah geçirilmesi haberleri de tehdit içeren, tehlikeli bir durumu ortaya koymaktadır. Bu haberlerde kullanılan 'sınır' kelimesi, 'öteki'den gelen tehdide karşı hazır durumda olmayı vurgulamaktadır. Haberlerin içeriği sınırda alınan güvenlik önlemlerini kapsamaktadır. '8 askerimizi şehit eden silahlar Suriye'den' haberinde, ülkeye gelen Suriyeli mültecilerin kaçak olarak getirdiği silahların askerimizi şehit ettiği vurgusu, korku yaratmakta ve Suriyelileri bütüncül bir şekilde düşman konumuna yerleştirmektedir. Buradaki askerimiz kelimesindeki 'miz' iyelik eki, biz ve öteki ayrımını inşa ederken, Suriyeliler tehdit ve tehlike içeren unsurlar olarak çerçevelenmektedir.

\section{(f) Güvenilir Kaynaklardan Alıntı Yapma}

'Gaziantep’te 25 Suriyeli gerginlik yaşanan mahalleden tahliye edildi' (Hürriyet, 02.07.2014), başlığıyla yayınlanan haberde Suriyeli işyeri sahiplerinin top oynayan çocukları döner bıçakları ile kovaladıkları ve bunun üzerine yaşanan gerginlik haberleştirilmiştir. Haber metninde "Suriyeliler" kelimesinin sık sık kullanılması, bireysel bir olaya kitlesel bir sorumlu bulma arayışı olarak belirgin bir şekilde görülmektedir. Haber söylemi ise, olaya şahit olan yerel kaynakların aktarımları üzerinden inşa edilmiştir. Bu bağlamda olayın bir tarafının aktarımları 'güvenilir' olarak haber metninde ön plana çıkartılırken, diğer taraftan herhangi bir aktarıma yer verilmemiştir.

'Kayseri'de Suriyelilere tepki yürüyüşü' (Hürriyet, 30.07.2014) başlıklı haberde, bir semtte Suriyeli mültecileri istemeyen yerli halkın yapmış olduğu gösteri haberleştirilmiştir. Haber metninde yerel kaynaklar ve emniyet güçlerinin aktarımları birincil kaynak olarak geniş çapta kendisine yer bulmuştur. Ayrıca bu açıklamalar ara başlık ve haber spotu olarak ön plana çıkarılmış ve gazetenin üretmek istediği söylemle bütünleşik bir bağlamda aktarılmıştır. Söylem çalışmalarında içselleştirme olarak adlandırılan bu durum, ilgili haber metninde de yoğun olarak gerçekleşmiştir.

'Suriyelilerin bulunduğu kampta isyan' (Hürriyet, 22.07.2012) başlıklı haberde haberinin başlığında kullanılan 'isyan' kelimesi ile askeri bir terminolojiye başvurulmuş ve Suriyelilerin tehlike düşüncesi ile ilişkilendirilmesi sağlanmıştır. Haber metninde emniyet kaynaklarından alınan bilgiler birincil kaynak olma bağlamında sık sık kullanılmıştır. Kaynak kullanımının tek yönlü olması sonucunda, haber söyleminin de bu doğrultuda geliştiği ve şekillendiği görülmektedir.

'Valilikten Suriyelilere uyarı: Kenti terk edin' (Sabah, 23.12.2014) ve 'Kızıltepe'de Tehlikeli Gerginlik' (Sabah, 24.07.2014) başlıklı haberlerde sık sık kullanılan tehlike ve gerginlik metaforları, Suriyelilere yönelik linç girişimlerini ve yerli halkla yaşanan çatışmaları ifade etmek üzere ön plana çıkarılmışıı. Güvenlik söyleminin çerçevesini çizdiği bu haberlerde, Suriyeli mülteciler ülkenin birlik ve bütünlüğüne yönelik bir tehdit olarak görülmektedir. Bu söylemi pekiştirme adına yerel kaynakların aktarımları yoğun olarak kullanılmış ve haber metninde birincil kaynak konumuna yerleştirilmiştir. 'Valilikten Suriyelilere uyarı: Kenti terk edin' başlıklı haberde, 'Suriyeliler' kelimesinin altı çizilmiştir. Özellikle 'Suriyelilere seslenildiği vurgulanmıştır. Bu haberin içeriğinde valinin 'onlarla birlikte yaşamanın yollarını arıyoruz' sözü güvenilir kaynak olarak sunulurken, biz ve onlar karşıtı̆̆ını haber söyleminde yeniden üretilmiştir. Haberde ayrıca sığınmacıların, Türk bayrağını indirip kendi bayraklarını astıkları yerel kaynaklardan alınan bilgiler çerçevesinde aktarılarak; Suriyeli mültecilerin olumsuz eylemlerin sorumlusu, 
'bizden olmayan' ve 'öteki' olarak sunulması sağlanmıştır. Burada Türk bayrağının indirilmesi iddiası, Türk ulusal söyleminin ve birliğinin inşasında gereksinim duyulan 'öteki'nin düşmanlaştırılmasına da aracılık etmektedir. Birlik ve beraberlik duygusunu oluşturacak şekilde milliyetçi söylem yeniden üretilmiş ve haber söyleminde bir tehdit olarak sunulan Suriyeliler, kendisine yapılan iyiliğe karşı 'nankör' ve 'saldırgan' gibi olumsuz ifadelerle tanımlanmıştır. 'Kızıltepe'de Tehlikeli Gerginlik' haberinin içeriğinde ise, Suriyeliler ile Kızıltepeli vatandaşlar arasında çıkan olayda, polisten kaçan grubun sadece Suriyeliler olması da toplumsal bir eşitsizliğin göstergesidir. Çünkü karşılıklı gerçekleşen olayda, sorun çıkaran, suçlu olarak nitelendirilen, açıklamalarına yer verilmeyen tek grup Suriyeli mülteciler olmuştur. Ayrıca bu iki haberde Suriyeli mültecilerin açıklamalarına ya da olaylarla ilgili değerlendirmelerine yönelik belirgin bir suskunluğun olduğu görülmektedir.

‘Gaziantep’te 25 Suriyeli gerginlik yaşanan mahalleden tahliye edildi’ başlıkı haberde, Suriyelilerin mahalle sakinleri ile yaşadığı gerginlik sonucu mahalleden gönderilmesi, toplumsal eşitsizliğin göstergesidir. Haber söyleminde sorun çıkaran ve tehdit unsuru olarak Suriyeliler gösterilirken, mahalle sakinleri mağdur olarak konumlandırılmıştır. Mahalle sakinlerinin açıklamalarına haber metninde geniş çapta yer verilirken ve olayın ardalan-bağlam bilgisine özellikle yer verilmemiştir. Bu doğrultuda haber söylemi tek yönlü bir anlamsal kapanmaya tabi tutularak, oluşturulmuştur.

'Mersin'de Suriyelilerin kimlik izdihamı' (Hürriyet, 29.05.2017), 'Çadır kentte 'özgürlük ve haklar' protestosu' (Milliyet, 18.07.2011), 'Mersin'de Suriyeli gerginliği' (Milliyet, 25.11.2013), 'Kayseri'de Suriyeli gerginliği' (Milliyet, 07.09.2014), 'Konya'da tehlikeli gerginlik! Suriyeliler ile...' haberinde 'Suriyeliler ile...' yazılarak üç nokta konulmuştur. Haber söylemin Suriyelilerin bu tür durumlara sebep oldukları, devam ettirdikleri gibi imalar; metinde ötekileştiren bir söylemin meşrulaştırması söz konusudur. Üç nokta olan kısma herhangi bir grup gelebilir fakat tehlikeli gerginliğe sebep olan Suriyelilerdir. Fakat haber söylemi oluşturulurken Suriyeli mültecilerin açıklamalarına yer verilmemiş olması dikkat çekmektedir. Bu haberde de yerel kaynaklar ve emniyet kuvvetlerinin açıklamaları haber metninde birincil kaynak pozisyonuna yerleştirilmiştir. Bu doğrultuda oluşan haber söylemi de ikili karşıtlıkların meşrulaştırıldığı bir zemin üzerinden inşa edilmiştir.

'Sağlık masrafları 191 milyon lira' (Milliyet, 09.12.2013), 'Bülbülü altın kafese koymuşlar ah vatanım demiş' (Hürriyet, 05.04.2012), 'Suriyelilere özel kimlik!' (Sabah, 08.10.2014) başlıklı haberlerde, Suriyeli sığınmacıların Türk vatandaşlarından daha ayrıcalıklı bir konumda olduğu imaları haber söylemlerinde ön plana çıkarılmıştır. Özellikle sağlık ve çalışma konulu haberde, Suriyelilerin hastanelerden ücretsiz yararlanmasından, Türkiye'ye göç edenlere verilecek kimliklerin çalışma hayatlarında kolaylık sağlayacağından bahsedilerek, 'Biz'den olmayana ayrıcalık tanındığına dair vurgular yapılır. Bu haberlerin genel söylemsel çerçevelerinde, 'biz/onlar' karşıtlığı doğrudan kurulmaktadır. Suriyelilere tanınması gündemde olan bu haklarla ilgili görüşler genellikle yerel kaynaklar üzerinden aktarılmış, konuyla ilgili kitlesel bir rahatsızlığın olduğu düşüncesi de haber söyleminde güçlendirilmiştir.

'Fatma Şahin'den 'Suriyelilere vatandaşlık' açıklaması (Milliyet, 16.07.2016) haberinde, Şahin'in Suriyelilere vatandaşlık verilmesi konusunda ilk olarak kendi vatandaşlarını, kendi esnafını düşünerek onların rahat edeceği bir model üzerinde, onların da görüş 
ve önerilerini alarak çok net duruş sergilediklerini vurgulaması, kurulan karşıtlığın göstergesidir. Görüş alınacak kişilerin yerli unsurlar olduğunun haber metninde ön plana çıkarıldığı görülmektedir. Bu durum haber metninde kullanılan 'esnafımız' ya da 'kendi vatandaşımız' kelimeleri ile daha da belirgin bir görünüm kazanmaktadır. Ayrıca diyalektik bir mantıkta haber söyleminde Suriyeli mültecileri 'karşıt' ve 'öteki' konumuna yerleştirmiştir. 'Bülbülü altın kafese koymuşlar ah vatanım demiş' başlıklı haberde ise, Suriyeliler için gereken her imkan sağlandığı halde yine de ülkelerinden kopamadıkları ifade edilmiştir. Bu konuyla ilgili yine yerel kaynakların yapmış olduğu durum değerlendirmeleri ve aktarımlara yer verilmiştir. Haber söyleminde yardıma muhtaçlıkları ölçüsünde Suriyeli sığınmacılara sağlanan imkanlar neticesinde 'biz' kendini 'öteki' karşısında olumlu sunmak istemiştir.

'Suriye'den yaşanan göç dalgası Kilisli kadınları kocalarından etti' (Milliyet, 20.02.2016) başlıklı haberde, Suriyeli mültecilerin ikinci eş olma durumunun, Türklerin aile değerlerine ahlak anlayışına zarar verdiği, bu değerleri kirlettiği vurgusu yapılır. Burada, Suriyeli sığınmacılar 'biz'i bozan, kirleten ötekiler konumuna yerleştirilerek, onlar için üretilmek istenen 'öteki kimliği' meşrulaştırılmıştır. Suriyeli kadınlarla yapılan evlilikler sonucu boşanmaların arttığı, Türk kadınlarının sahipsiz kaldığı bilgileri haberlerde öne çıkartılarak, ötekileştirme daha da güçlü kılınmıştır. Haberde yer verilen haber kaynakları açısından da tek yanlı bir kaynak aktarımı söz konusu olmuştur. Özellikle bölgede yaşayan yerel kişilerin aktarımlarına haber metninde yer verilerek, tek taraflı bir bilgi akışı sağlanmak istenmiştir.

\section{Sonuç}

Bu çalışma kapsamında da, Suriyeli mültecilerin Türkiye'deki gazetelerde temsili örneklem olarak seçilmiş olan üç kitle gazetesi üzerinden incelenmiştir. Mültecilerle ilgili ötekileştirici-ayrıştırıcı tutum ve davranışların kamuoyunda yaygınlaşmasında, diğer toplumsal ve siyasal faktörlerin yanı sıra, özellikle haber medyasında gerçekleştirilen temsillerin oldukça önemli olduğu bilinmektedir. Ayrıca haber medyası; trajik olanı bir malzemeye dönüştüren, gösteri özelliği taşıyan detayları ön plana çıkaran ve insani konuları görmezden gelen yapısıyla mültecilerle ilgili geliştirilen söylem ve temsil biçimlerinin oldukça sorunlu bir yapı çerçevesinde oluşmasına neden olmaktadır (Çakır, 2013: 119-120). Haber medyasında mültecilerle ilgili üretilen haberlerin söylemlerini analiz etmek, haber medyasında üretilen egemen söylemlerin nasıl meşru hale getirildiği, bu durumun toplumsal bilinçte ve hayattaki ayrıştırıcı-ötekileştirici düşünceleri nasıl beslediğini ortaya koyması açısından önem taşımaktadır.

Yapılan analizler sonucunda ortaya çıkan bulgular ışığında, gazetelerin mültecilerle ilgili haberlerde kullanmış oldukları Suriyeli mülteci temsilleri belirli konu başlıkları etrafında toparlanmaktadır. Çalışmanın temel kurgulanma amacı çerçevesinde, mültecilerin temsilindeki ötekileştirici söylemler ve bu söylemlerin üretim sürecinde ne gibi eğilimlerin ya da konuların etkili olduğu belirlenmiştir. Bu bağlamda aşağıda sıralanan temel eğilimler ve yöntemler doğrultusunda ötekileştirici söylemlerin kategorilere ayrıldığı ve bu kategorilerdeki önceliklere uygun şekilde üretildiği görülmüştür. Her bir eğilimin odaklanmış olduğu temel çerçeveler ve kurallar doğrultusunda ayrıştırıcı ve ötekileştirici söylemlerin üretildiği görülmektedir. Bu kategoriler sırasıyla:

(a) Yargılama (Gerçeklerden Kaynaklanarak Olumsuz Değerlendirmeler Yapma) 
(b) Retorik Görünüm (Olumlu Davranışların Gizlenmesi-Olumsuz Davranışların Ön Plana Çıkarılması)

(c) Lexical Stil (Negatifliği ya da Pozitifliği İma Eden Kelime Tercihleri)

(d) Hikayeleştirme: (Yaşanılan Olumsuzlukları Kişisel Deneyimlere İndirgeme)

(e) Olumsuz Davranışların Yapısal Vurgusu: (Başlıkta, Spotta, Ara Başlıkta, Girişte, Diğerine Ait Olumsuz Davranışlara Yer Verme).

\section{(f) Güvenilir Kaynaklardan Alıntı Yapma}

$\mathrm{Bu}$ çerçevede bütün bu kategorilerin farklı odaklanma noktaları ve metotlarıyla üretilmiş ve meşrulaştırılmış 'ayrıştırıcı-ötekileştirici' söylemlerinin dolaşıma sokulduğu görülmüştür. Bu söylemlerin çeşitli konu başlıkları üzerinden dolaşıma sokulduğu da elde edilen önemli bulgulardan birisi olarak görülmektedir. Bu bağlamda yazılı basında yer alan haberlerde Suriyeli mültecilere ilişkin haberlerin ilk örneklerinde mülteciler 'misafir' olarak konumlandırılmıştır. Bu konumlandırma özünde "ötekileştirici" bir tutum ya da davranış barındırmıyor gibi gözükse de, Suriyeli mülltecilerin haber söyleminde "bizden olmayan" anlatısı ekseninde konumlandırılması, ayrıştırıcı bir bakış açısının metinde üretilmesine neden olmuştur. Haber metinlerinde mültecilerin temsili için benimsenen bu yaklaşım; sığınmacıların kalış sürelerinin uzaması, kaldıkları yerlerdeki sosyal ve kültürel yapıyı etkilemeleri, günlük yaşamda sebep oldukları bazı sorunlar gibi nedenlerden ötürü kısa zaman içinde hızlı bir değişim göstermiştir.

Bu doğrultuda medyada Suriyeli mültecilerin ötekileştirilen bir bağlam ekseninde ele alındığı bir başka konu; "korkulan kişi olma" ya da "sorun çıkartan kişi olma" anlatısı üzerinden temsil edilmeleri olmuştur. İncelenen haberlerin birçoğunda fobik (korku ve nefret uyandıran) temsillerinin yer aldığı görülmüştür. Suriyeli mültecilerin sebep olduğu sorunları konu edinen haber metinleri içerisinde Türkiye Cumhuriyeti vatandaşlarının haber kaynağı olarak kullanılması ve tanımlamalarına geniş çapta yer ayrılması örtük olarak Suriyeli mültecileri haber söyleminde "öteki” konumuna yerleştirmiştir.

Benzer şekilde Suriyeli mültecileri "öteki" olarak haber metninde konumlandırma sürecinde ön plana çıkan bir başka konu başlığı ise, mültecilerin karışmış oldukları suç olayları ve Avrupa'ya gitmek için giriştikleri kaçak göç faaliyetleri olmuştur. Bu haberlerde suça karışan mültecilerin Suriyeli olduğu hem haber başlıklarında hem de haber metinlerinde sık sık tekrar edilmiştir. Gazeteler "Suriyeli-hırsız", "Suriyeliinsan taciri", "Suriyeli-kaçak", "Suriyeli öteki" gibi kalıp anlatılar sayesinde 'suç' kavramı ile ilişkilendirmekten kaçınmamıştır. Ayrıca kaçak göç faaliyetlerini konu edinen haberlerde 'yasadışı' ve 'kaçak' kelimelerinin yoğun olarak kullanıldığı ve bu kelimelerin haber başlıklarında ve ara başlıklarda kullanıldığı dikkat çekmektedir. Özellikle "yasadışı" kelimesinin sadece yasanın ihlal edilmesi anlamına gelmediği, üretilen haber söylemlerinde mültecileri suçla ilişkilendiren bir bağlama yerleştirildiği dikkat çekmektedir. Bu anlatım Suriyeli mültecileri suçla ilişkilendirdiği için toplumsal bilinçte mültecilere yönelik ötekileştirici bir algının benimsenmesine neden olmaktadır. 
ise sosyal hayat ve ahlaki dejenerasyon kapsamında oluşturulmuştur. Bu haberlerin söylemlerinde Suriyeli mültecilerin kent hayatındaki "aşırı görünürlüğü" "görüntü kirliliğine sebep olmaları", "ikinci eş olmaları" gibi konularla ilişkilendirilerek temsil edildikleri görülmüştür. Bu bağlamda Suriyeli Mülteciler, fiziki olarak kent yaşamını bozmanın yanında ahlaki değerleri de kirleten aktörler olarak haber söylemlerinde "öteki" olarak işaretlenmiştir. Ayrıca haber metinlerinde Türkiye Cumhuriyeti vatandaşları ile karşılaştırılarak sürekli çatışma içerisinde sunulan mültecilerin sosyal hayatta sebep oldukları olumsuzlukların ve sorunların vurgulanması, haber söylemlerinde "biz" ve "onlar" karşıtlığının kolaylıkla kurulmasına ve sıradanlaşmasına da aracılık etmiştir.

Suriyeli mültecilerin haber söylemlerinde "öteki" pozisyonuna yerleştirilerek temsil edildiği bir başka konu grubu ise Ekonomiye ve iş gücüne bıraktıkları düşünülen olumsuz etkiler üzerinden anlatıya dönüştürülmüştür. $\mathrm{Bu}$ haberlerin söylemsel çerçeveleri Suriyeli mültecilerin sebep olduğu ekonomik sorunlarla ilgili rakamsal ifadelerin tekrarı ve Türkiye Cumhuriyeti vatandaşlarının hayatına getirdiği ekonomik yükümlülükler şeklinde oluşturulmuştur. Bu bağlamda Suriyeli mültecilerin doğrudan ekonomik sorunların kaynağıymış gibi anlatıldığı haber söylemleri dikkat çekmektedir. Özellikle ekonomi, iş gücü ve mültecilerin sayıları ile ilgili haberlerde ekonomik külfetten, kira artışlarından, iş gücü kaybından, ucuz iş gücü gibi sorunların kaynağı olarak Suriyeli mültecilerin gösterilmesi, haber metinlerinde örtük olarak Suriyeli mültecileri "öteki" olarak konumlandırmasına neden olmuştur. Ayrıca haber metinlerinde üretilen ötekileştirici söylemlerin; mülteci sorununun insani boyutu yerine harcanan para, yapılan yardımlar, mültecilerin sayısı gibi daha normal konular sayesinde gizlendiği görülmüştür.

Haber metinlerinin üretim sürecindeki en önemli unsurlardan birisi olan haber kaynağı kullanımında da, Suriyeli mültecilere eşit hak ve alanların verilmediği görülmüştür. Haberlerde temel kaynaklar emniyet yetkilileri ya da Türkiye Cumhuriyeti vatandaşları arasından seçilerek, Suriyeli mültecilerin kendileri ile ilgili haber metinlerinden uzak tutulması sağlanmıştır. Bu doğrultuda kullanılan her açıklama doğal olarak ötekileştirici söylemlerin haber metinlerinde üretilmesini kolaylaştırmıştır. Sonuç olarak bu çalışma üzerinden, Suriyeli mültecilerin gazete haberlerindeki temsillerinde ötekileştirici unsurlara yer verildiği ve bu temsillerin belirli konu başlıkları etrafında toparlandığı görülmektedir. Bu bağlamda Suriyeli mültecilerin günlük hayatlarından normal temsiller yerine; kitlesel etki düzeyine sahip haber medyası ayrıştırıcı ve ötekileştirici söylemler üzerine inşa edilmiş bir Suriyeli mülteci temsiline yer vermektedir. Bu sorunun çözümü adına öncelikle haber metinlerinin üretim süreçlerinde kullanılan ayrıştırıcı dil ve tanımlama kalıplarına yer verilmemesi gerekmektedir. Ayrıca haber medyasında olumsuz örnekler üzerinden temsil ve bu temsil süreçlerinde etnik köken ya da uyruk gibi ifadelerin haber söylemlerinde ön plana çıkarılmaması; sorunun çözümü için katkı sağlayacak bir önlem olarak değerlendirilmelidir. Bundan sonra yapılacak çalışmalar açısından; benzer anlatımların yeni medya mecralarındaki yansımaları ve bu süreçte ne tür tipolojilerin oluştuğu konusu ele alınabilir.

\section{Kaynakça}

Akca, Emel Baştürk (2009). “ideoloji-Dil-Söylem ve Anlam İlişkisi: Medyada Anlamın Toplumsal İnşası", Medyada gerçekliğin İnşası/Türk Medya Söylemine Eleştirel Bir Bakış, (Ed. İsmet Parlak) Konya: Çizgi Kitabevi. 77-106. 
Akçalı, Selda (2006). Gündelik Hayat ve Medya: Tüketim Kültürü Perspektifinden Okumalar, Ankara: Ebabil Yayıncılık.

Bauman, Zygmunt (2005). Bireyselleşmiş Toplum, Yavuz Alogan (çev.), İstanbul: Ayrıntı Yayınları.

Bauman, Zygmunt (2009). Sosyolojik Düşünmek, Abdullah Yılmaz (çev.), İstanbul: Ayrıntı Yayınları.

Birleşmiş Milletler Mülteciler Yüksek Komiserliği (2017). Syria Regional RefugeeResponse,http:// data.unhcr.org/syrianrefugees/regional.php\#_ga=1.150812086.1634584225.1465540161, Erişim Tarihi: 20 Ağustos 2017.

Birleşmiş Milletler Mülteciler Yüksek Komiserliği, (1998). Sığınma ve Mülteci Konularındaki Uluslararası Belgeler ve Hukuki Metinler, Ankara: BMMYK Türkiye Temsilciği.

Boztepe, Veli (2017). "Televizyon Haberlerinde Suriyeli Mültecilerin Temsili”, Ankara Üniversitesi İlef Dergisi, Sayı 4/1: 91-122.

Buehler, Arthur (2011). "Islamophobia: A Projection of the West's Dark Side", Islam and Civilisational Renewal, 2(4): 639-653.

Cottle, Simon (2000). "Media Reserach and Ethnic Minorities: Mapping The Field", Simon Cottle, (Ed.), Ethnic Minorities and Media: Changing Cultural Boundaries, Philadephia: Open University Press. 1-30.

Çakır, Mukadder (2013). "Internet Haberciliğinde Yasadışı Göç Sorunu,", Online Academic Journal of Information Technology, Cilt 4/Sayl: 12: 105-124.

Çelenk, Sevilay (2010). "Ayrımcılık ve Medya," Televizyon Haberciliğinde Etik Sorunlar, Bülent Çaplı ve Hakan Tuncel (Ed.), Ankara: Fersa Yayıncılık. 211-228.

Dursun, Çiler (2004). "Haberde Gerçekliğin İnşa Edilmesi Ne Demektir?", Haber, Hakikat ve İktidar Iliş̧kisi, Çiler Dursun (Ed.), Ankara: Elips Kitap. 37-65.

Fairclough, Norman (1993). "Critical Discourse Analysis and Marketization of Public Discourse in Universities: The Universities”, Discourse and Society, Vol. 4 (2): 133-168.

Fairclough, Norman (2001). Language and Power, London: Longman.

Fairclough, Norman and Wodak, Ruth (1997). "Critical Discourse Analysis", Introduction to Discourse Analysis, van Dijk, Teun (Ed.), London: Sage Publication: 258-284.

Göker, Göksel ve Keskin, Savaş (2015). "Haber Medyası ve Mülteciler: Suriyeli Mültecilerin Türk Yazılı Basınındaki Temsili”, Iletişim Kuram ve Araştırma Dergisi, sayı 41: 229-256.

Güçtürk, Yavuz (2014). Sürgün ile Savaş Arasında Suriyeli Mülteciler, Siyaset. Ekonomi ve Toplum Araştırmaları Vakfı (SETA), Ankara, Erişim Tarihi. : Temmuz 2017, http://setav.org/tr/5soru-surgun-ile-savas-arasinda-suriyeli-multeciler/yorum/18059. 
Hackett, Samuel (2005). "Is there a democratic deficit in US and UK journalism?", Journalism: Critical Issues, Stuarth Allan, (Ed.), New York: Open University Press. 85-97.

Hall, Stuart (2001). "Encoding and Decoding", Media and Cultural Studies, Douglas Kellner (Ed.), London: Blackwell. 166-177.

Hobsbawm, Eric (2006), Milletler ve Milliyetçilik: Program, Mit, Gerçeklik, Osman Akınhay (çev.), İstanbul: Ayrıntı Yayınları.

İnal, Ayşe (1996). Haberi Okumak, İstanbul: Temuçin Yayınları.

İnceoğlu, Yasemin ve Çomak, Nebahat (2009). Metin Çözümlemeleri, İstanbul: Ayrıntı Yayınları.

Karaduman, Sibel (2007). "Medyatik Gerçeklikte Kimlik Temsilleri: Televizyon Haberlerinin Aktörleri Üzerine Düşünceler", Selçuk Iletişim, Vol.4, No: 4: 45-56.

Kaya, Ayhan (2015). "Euro-Türkler, Kuşaklararası Farklıııklar, İslam ve Entegrasyon Tartışmaları", Göç Araştırmaları Dergisi, 1(1): 44-79.

Kearney, Richard (2012). Yabancılar, Tanrılar ve Canavarlar: Ötekiliği Yorumlamak, Barış Özkul (çev.), İstanbul: Metis Yayınları.

Matheson, Donald (2005). Media Discourses: Analysing Media Texts, London: Open University Press.

Nurdoğan, Ali Kemal ve vd., (2017). "Türkiye'nin Mülteci Sorunu ve Suriye Krizinin Mülteci Sorununa Etkileri”, iş̧ ve Hayat Dergisi, Sayı 4: 217-238.

Onur, Hilal (2003). "Öteki Sorunsalının 'Alterite' Kavramı Çerçevesinde Yeniden Okunması Üzerine Bir Deneme”, Hacettepe Üniversitesi İktisadi ve İdari Bilimler Fakültesi Dergisi, 21,(2): 255-277.

Özdemir, Fatih ve Öner-Özkan, Bengi (2016). “Türkiye'de Sosyal Medya Kullanıcılarının Suriyeli Mültecilere İlişkin Sosyal Temsilleri”, Nesne Psikoloji Dergisi, Cilt 4, Sayı 8: 227-244.

Özsüer, Esra (2012). “Türk-Yunan Illişkilerinde ‘Biz’ ve ‘Öteki' Önyargıların Dinamikleri”, Avrasya İnceleme Dergisi, 1/2 (2012): 269-309.

Said, Edward (1999). Şarkiyatçıık: Batı'nın Şark Anlayışları, Berna Ülner (çev.), İstanbul: Metis Yayınları.

Seydi, Ali Rıza (2014). "Türkiye'nin Suriyeli Sığınmacıların Eğitim Sorununun Çözümüne Yönelik İzlediği Politikalar”, Süleyman Demirel Üniversitesi Fen Edebiyat Fakültesi Sosyal Bilimler Dergisi, Sayı: 31: 267-305.

Shoemaker, Pamela ve Reese, Stephen (2002) “Ideolojinin Medya İçeriği Üzerindeki Etkisi”, Medya Kültür Siyaset, Süleyman İrvan(Der.), Ankara: Ark Yayınları. 127-178. 
Sözen, Edibe (1999). Söylem: Belirsizlik, Mübadele, Bilgi/Güç ve Refleksivite, İstanbul: Paradigma Yayınları.

Şeker, Mustafa ve Şimşek, Fadime (2011). "Ötekilik Bağlamında 'Muhteşem Yüzyıl' Dizisinin Farkıı İdeolojideki Gazetelerin Köşe Yazılarına Yansıması", Türkiyat Araştırmaları Dergisi, No: 29: 483-509.

Tuchman, Gaye (1978). Making News: A Study in the Construction of Reality, New York: The Free Press.

Tunç, Ayşe Şebnem (2015). "Mülteci Davranışı ve Toplumsal Etkileri: Türkiye'deki Suriyelilere iliş̧kin Bir Değerlendirme", Tesam Akademi Dergisi, Temmuz 2015, 2(2): 29-63.

Uluç, Güliz (2009). Medya ve Oryantalizm Yabancı, Farklı ve Garip... Öteki, İstanbul: Anahtar Kitaplar Yayınevi.

Ünür, Ece (2013). "Görünmeyen Kimlikler: Öteki Kimliği Bağlamında ‘Kayıp Şehir' Dizisinin Analizi", Akademik İncelemeler Dergisi, 8,(2): 251-273.

van Dijk, Teun (1989). "Social Cognition and Discourse", Handbook of Social Psychology and Language, Howard Giles \& Peter Robinson (Eds.), Chichester: Wiley. 163-183.

van Dijk, Teun (1991). Racism and the Press, Newyork: Routledge.

van Dijk, Teun (1993). "Principles of Critical Discourse Analysis", Discourse \& Society, Volume 4 (2): 249-283.

van Dijk, Teun (1995). Aims of Critical Discourse Analysis, Japanese Discourse, 1 (1): 17-28.

van Dijk, Teun (2000). "New(s) Racism", Simon Cottle (Ed.), Ethnic Minorities and The Media, London: Open University Press. 33-49.

van Dijk, Teun (2001). "Critical Discourse Analysis", Deborah Tannen, Deborah Schiffrin \& Heidi Hamilton (Eds.), Handbook of Discourse Analysis, Oxford: Blackwell. 352-371.

van Dijk, Teun (2003). "Söylem ve İdeoloji: Çok Alanlı Bir Yaklaşım," Söylem ve İdeoloji, Barış Çoban ve Zeynep Özarslan (Ed.), İstanbul: Su Yayınları. 13-112.

van Dijk Teun (2005). "Söylemin Yapıları ve İktidarın Yapıları", Medya İktidar İdeoloji. Mehmet Küçük (der.ve çev.), Ankara: Bilim ve Sanat Yayınaları. 315-359.

van Dijk, Teun (2008). Discourse and Context: A Sociocognitive Approach, Cambridge: Cambridge University Press. 